Review

\title{
Exopolysaccharides Produced by Lactic Acid Bacteria: From Biosynthesis to Health-Promoting Properties
}

\author{
Dominika Jurášková, Susana C. Ribeiro (D) and Celia C. G. Silva *D \\ Institute of Agricultural and Environmental Research and Technology (IITAA), University of the Azores, \\ 9700-042 Angra do Heroísmo, Azores, Portugal; dominika.juraskova@gmail.com (D.J.); \\ susana.ic.ribeiro@uac.pt (S.C.R.) \\ * Correspondence: celia.cg.silva@uac.pt; Tel.: +351-2954-02200
}

check for updates

Citation: Jurášková, D.; Ribeiro, S.C.; Silva, C.C.G. Exopolysaccharides Produced by Lactic Acid Bacteria: From Biosynthesis to

Health-Promoting Properties. Foods 2022, 11, 156. https://doi.org/

10.3390 /foods 11020156

Academic Editor: Albert Bordons

Received: 15 December 2021

Accepted: 4 January 2022

Published: 8 January 2022

Publisher's Note: MDPI stays neutral with regard to jurisdictional claims in published maps and institutional affiliations.

Copyright: (C) 2022 by the authors. Licensee MDPI, Basel, Switzerland. This article is an open access article distributed under the terms and conditions of the Creative Commons Attribution (CC BY) license (https:// creativecommons.org/licenses/by/ $4.0 /)$.

\begin{abstract}
The production of exopolysaccharides (EPS) by lactic acid bacteria (LAB) has attracted particular interest in the food industry. EPS can be considered as natural biothickeners as they are produced in situ by LAB and improve the rheological properties of fermented foods. Moreover, much research has been conducted on the beneficial effects of EPS produced by LAB on modulating the gut microbiome and promoting health. The EPS, which varies widely in composition and structure, may have diverse health effects, such as glycemic control, calcium and magnesium absorption, cholesterol-lowering, anticarcinogenic, immunomodulatory, and antioxidant effects. In this article, the latest advances on structure, biosynthesis, and physicochemical properties of LAB-derived EPS are described in detail. This is followed by a summary of up-to-date methods used to detect, characterize and elucidate the structure of EPS produced by LAB. In addition, current strategies on the use of LAB-produced EPS in food products have been discussed, focusing on beneficial applications in dairy products, gluten-free bakery products, and low-fat meat products, as they positively influence the consistency, stability, and quality of the final product. Highlighting is also placed on reports of health-promoting effects, with particular emphasis on prebiotic, immunomodulatory, antioxidant, cholesterol-lowering, anti-biofilm, antimicrobial, anticancer, and drug-delivery activities.
\end{abstract}

Keywords: exopolysaccharides; EPS; lactic acid bacteria; LAB; structure; biosynthesis; food application; health; prebiotics; probiotics

\section{Introduction}

It is well-known that lactic acid bacteria (LAB) can synthesize a variety of polysaccharides. These comprise a large group of high-molecular-weight molecules consisting of monosaccharide units linked by a glycosidic bond, which exhibit a variety of structures, functional properties, and biological activities [1,2]. Polysaccharides are one of the main components involved in the formation of the extracellular biofilm matrix. They play an important role not only in protecting bacteria from adverse environmental factors, but also in the attachment of microbial cells to solid surfaces [3-6]. The polysaccharides produced by bacteria can be found in structures on the cell surface classified as capsular polysaccharides or lipopolysaccharides [7]. They form the outermost layer of the bacterial cell and provide a mechanism to protect the cell, mediating direct interactions with the environment. Due to their attachment to the cell surface, they are unlikely to be isolated or separated from the cell biomass, although some capsular polysaccharides can be released from the cell. In contrast, exopolysaccharides are polysaccharides that are loosely associated with the cell surface or released into the extracellular medium [8,9]. They can either be produced extracellularly by enzymes secreted by the bacterium, or synthesized intracellularly and secreted outside the cells [10]. Considering the protective mechanisms for the microbial cell, such as protection against abiotic or biotic stress, competition, $\mathrm{pH}$, and temperature, exopolysaccharides (EPS) have particular physicochemical properties that most likely have 
potential for the food and pharmaceutical industries. Nevertheless, most of the research is focused on the application of EPS in the food industry due to their structural properties, such as emulsification, texturization, sweetening, gelling, water-binding capacity, or bioactive properties. This is one of the reasons why EPS has attracted the attention of researchers. Recent studies have also demonstrated the health-promoting potential of EPS, including immunomodulatory, prebiotic, anti-inflammatory, anti-biofilm, and antioxidant activities [11-15]. In this review, the structure of EPS produced by LAB, their biosynthesis, and the methods currently used to isolate and characterize EPS are described. In addition, some food and pharmaceutical applications of EPS are discussed, as well as the recent evidence of health-promoting effects of EPS.

\section{Structure of Exopolysaccharides (EPS)}

Bacterial EPSs have diverse and complex chemical structures that strongly influence their functional properties and biological functions. They can be divided into homopolysaccharides (HoPS), which contain a single type of monosaccharide, and heteropolysaccharides (HePS), which consist of two or more types of monosaccharides [16-18]. Most of the EPS produced by LAB are HePS and are synthesized intracellularly, while some LAB species/strains produce HoPS by extracellular enzymes $[10,19]$. The HoPS produced by LAB (Table 1) can be classified as glucans, fructans, or galactans, which consist of D-glucose, D-fructose, or D-galactose, respectively [10,20]. Glucans consist of glucose residues as the main backbone structure with different degrees of branching and binding sites that vary from bacterial strain to bacterial strain. Glucans can be classified as either $\alpha$-glucans or $\beta$-glucans, and are produced by a variety of LAB species in the genera Leuconostoc, Lactobacillus, Streptococcus, and Weissella [21]. Alpha-glucans can be divided into four groups: (i) dextran is water-soluble and mostly has $\alpha-(1 \rightarrow 6)$ bonds, although some branching may occur at $\alpha-(1 \rightarrow 2), \alpha-(1 \rightarrow 3)$ or $\alpha-(1 \rightarrow 4)$ [22,23]; (ii) mutan is generally water-insoluble and contains mainly $\alpha-(1 \rightarrow 3)$ bonds with branching at $\alpha-(1 \rightarrow 6)$ [21]; (iii) reuteran is a water-soluble branched $\alpha$-glucan consisting of $\alpha$ - $(1 \rightarrow 4)$-linear fragments linked by $\alpha-(1 \rightarrow 6)$ bonds [24]; and (iv) alternan exhibits alternating $\alpha-(1 \rightarrow 3)$ and $\alpha-(1 \rightarrow 6)$ bonds and shows lower viscosity and higher solubility in water [25]. Beta-glucans are also HoPS, produced by Pediococcus and Streptococcus spp., and consist of D-glucose linked by $\beta-(1 \rightarrow 3)$ bonds together with $\beta-(1 \rightarrow 2)$ branches $[19,26]$. Fructans are water-soluble fructose polymers produced by strains of Streptococcus salivarius, Leuconostoc mesenteroides, Limosilactobacillus reuteri (formerly Lactobacillus reuteri), Lactobacillus johnsonii and Fructilactobacillus sanfranciscensis (formerly Lactobacillus sanfranciscensis). They can be divided into (i) levan with $\beta-2,6$ link(ages and (ii) inulin with $\beta-2,1$ linkages [27]. The water-soluble galactans are less abundant, have $\alpha-(1 \rightarrow 6)$-linked galactose units, and are produced by a few LAB strains belonging to Weissella confusa, Lactococcus lactis subsp. lactis and Lactobacillus delbrueckii subsp. bulgaricus $[19,28]$. 
Table 1. Homopolysaccharides produced by lactic acid bacteria.

\begin{tabular}{|c|c|c|c|c|}
\hline HoPS & & LAB & Mw/Structure & Reference \\
\hline \multirow[t]{4}{*}{$\alpha$-D-glucans } & Dextran & $\begin{array}{c}\text { Leuconostoc mesenteroides } \\
\text { Leuconostoc citreum } \\
\text { Leuconostoc pseudomesenteroides } \\
\text { Lentilactobacillus parabuchneri (formerly } \\
\text { Lactobacillus parabuchneri) } \\
\text { Limosilactobacillus fermentum (formerly } \\
\text { Lactobacillus fermentum) } \\
\text { Limosilactobacillus reuteri (formerly } \\
\text { Lactobacillus reuteri) } \\
\text { Latilactobacillus sakei (formerly } \\
\text { Lactobacillus sakei) } \\
\text { Latilactobacillus curvatus (formerly } \\
\text { Lactobacillus curvatus) } \\
\text { Lactobacillus hordei } \\
\text { Lactobacillus nagelli } \\
\text { Lactobacillus mali } \\
\text { Lactobacillus satsumensis } \\
\text { Weissella confusa } \\
\text { Weissella cibaria } \\
\text { Streptococcus mutans } \\
\text { Streptococcus salivarius }\end{array}$ & $\begin{array}{c}\text { Mw: } 10^{3}-10^{7} \mathrm{Da} \\
\alpha-\mathrm{D}-\mathrm{Glc}(1,6)\end{array}$ & [29-47] \\
\hline & Mutan & $\begin{array}{l}\text { Limosilactobacillus reuteri } \\
\text { Streptococcus downei } \\
\text { Streptococcus mutans } \\
\text { Streptococcus salivarius }\end{array}$ & $\begin{array}{c}\mathrm{Mw}:>10^{6} \mathrm{Da} \\
\alpha-\mathrm{D}-\mathrm{Glc}(1,3)\end{array}$ & {$[35,36,40,48-50]$} \\
\hline & Alternan & $\begin{array}{l}\text { Leuconostoc mesenteroides } \\
\text { Streptococcus salivarius } \\
\text { Leuconostoc citreum }\end{array}$ & $\begin{array}{c}\mathrm{Mw}:>10^{6} \mathrm{Da} \\
(\alpha-\mathrm{D}-\mathrm{Glc}(1,6) / \alpha-\mathrm{D}- \\
\operatorname{Glc}(1,3)\end{array}$ & [51-53] \\
\hline & Reuteran & Limosilactobacillus reuteri & $\begin{array}{c}\mathrm{Mw}: 10^{7} \mathrm{Da} \\
\alpha \text {-D-Glc }(1,4) / \alpha-\mathrm{D}- \\
\operatorname{Glc}(1,6)\end{array}$ & {$[40,54]$} \\
\hline$\beta$-Glucans & & $\begin{array}{l}\text { Lactobacillus suebicus } \\
\text { Pediococcus parvulus }\end{array}$ & $\begin{array}{l}\text { Mw: } 10^{5}-10^{6} \mathrm{Da} \\
\text { [ } \beta \text {-D-Glc }(1,3) \text { with side } \\
\text { chain linked }(1,2)]\end{array}$ & {$[55,56]$} \\
\hline \multirow[t]{2}{*}{ Fructans } & Levans & $\begin{array}{c}\text { Leuconostoc mesenteroides } \\
\text { Limosilactobacillus reuteri } \\
\text { Streptococcus mutans } \\
\text { Bacillus subtilis }\end{array}$ & $\begin{array}{c}\text { Mw: } 10^{4}-10^{8} \text { Da } \\
\beta-D-F r u(2,6)\end{array}$ & {$[47,57]$} \\
\hline & Inulin-type & $\begin{array}{c}\text { Streptococcus mutans } \\
\text { Limosilactobacillus reuteri } \\
\text { Leuconostoc citreum } \\
\text { Lactobacillus johnsonii }\end{array}$ & $\begin{array}{c}\text { Mw: } 10^{3}-10^{7} \mathrm{Da} \\
\beta-\mathrm{D}-\operatorname{Fru}(2,1)\end{array}$ & {$[20,55,58,59]$} \\
\hline Polygalactan & & $\begin{array}{c}\text { Lactococcus lactis } \\
\text { Lactobacillus delbruecki }\end{array}$ & $\begin{array}{l}\text { pentameric repeating } \\
\text { unit of galactose }\end{array}$ & {$[47]$} \\
\hline
\end{tabular}

HePS (Table 2), unlike HoPS, have a more complex structure as they are composed of several repeating units of sugars, such as pentose (D-ribose, D-arabinose, D-xylose), hexose (D-glucose, D-galactose, D-mannose), $\mathrm{N}$-acetylated monosaccharides ( $\mathrm{N}$-acetylglucosamine and $\mathrm{N}$-acetyl-galactosamine), or uronic acids (D-glucuronic acid, D-galacturonic acid), and may be branched or unbranched $[8,60,61]$. They are produced by members of the genera Lactobacillus, Lactococcus, and Streptococcus [10]. HePS are produced in relatively small amounts by LAB but exhibit high thickening power at low concentrations $[20,62,63]$. Kefiran is an example of HePS produced by several Lactobacillus species in kefir grains, including L. kefiranofaciens, L. kefirgranum, L. parakefir, L. kefir, and L. delbrueckii subsp. bul- 
garicus [64]. Kefiran is a water-soluble branched glucogalactan with a complex structure consisting of D-glucose (Glc) and D-galactose (Gal) in approximately equal amounts, with $(1 \rightarrow 6)$-linked Glc, $(1 \rightarrow 3)$-linked Gal, $(1 \rightarrow 4)$-linked Gal, $(1 \rightarrow 4)$-linked Glc, and $(1 \rightarrow 2,6)$ linked Gal [65]. Because of these types of linkages, kefiran cannot be hydrolyzed by the digestive enzymes of the human gastrointestinal tract, but it can be fermented by colon bacteria [64]. Other water-soluble HePS include gellan and xanthan, but they are produced by non-LAB, such as Sphingomonas paucimobilis and Xanthomonas campestris [66].

Table 2. Heteropolysaccharides produced by lactic acid bacteria.

\begin{tabular}{|c|c|c|c|}
\hline LAB & HePS Composition & Molecular Weight & Reference \\
\hline Streptococcus thermophilus CC30 & Glucose, galactose & 58 to $180 \mathrm{kDa}$ & [67] \\
\hline Streptococcus thermophilus CH101 & Glucose, galactose & $8.5 \times 10^{5} \mathrm{Da}$ & {$[68]$} \\
\hline Streptococcus thermophilus LY03 & Glucose, galactose, N-acetylgalactosamine & $1.8 \times 10^{6} \mathrm{Da}$ & [68] \\
\hline Streptococcus thermophilus S-3 & N-acetylgalactosamine, galactose, glucose & $5.7 \times 10^{5} \mathrm{Da}$ & [69] \\
\hline Streptococcus thermophilus NIZO2104 & $\begin{array}{c}\text { Galactose, ribose, } \\
\mathrm{N} \text {-acetylgalactosamine, glucose }\end{array}$ & $0.9 \times 10^{6} \mathrm{Da}$ & {$[70,71]$} \\
\hline Streptococcus thermophilus AR333 & Galactose, glucose, galactosamine & $3.1 \times 10^{5} \mathrm{Da}$ & {$[72]$} \\
\hline $\begin{array}{l}\text { Lactobacillus delbruecki subsp. } \\
\text { bulgaricus CNRZ } 1187\end{array}$ & $\begin{array}{l}\text { Rhamnose, arabinose, mannose, } \\
\text { galactose, glucose }\end{array}$ & $10^{4}-10^{6} \mathrm{Da}$ & {$[73,74]$} \\
\hline $\begin{array}{l}\text { Lactobacillus delbruecki subsp. } \\
\text { bulgaricus DGCC291 }\end{array}$ & Glucose, galactose & $1.4 \times 10^{6} \mathrm{Da}$ & {$[70,71]$} \\
\hline $\begin{array}{l}\text { Lactobacillus delbruecki subsp. } \\
\text { bulgaricus NCIMB702074 }\end{array}$ & Glucose, galactose & $1.8 \times 10^{6} \mathrm{Da}$ & {$[70,71]$} \\
\hline $\begin{array}{l}\text { Lacticaseibacillus casei (formerly } \\
\text { Lactobacillus casei) WXD030 }\end{array}$ & Glucose, glucosamine, mannose & $37.37 \mathrm{kDa}$ & [75] \\
\hline Lactobacillus gasseri FR4 & Glucose, mannose, galactose, rhamnose, fucose & $1.9 \times 10^{5} \mathrm{Da}$ & [76] \\
\hline Lactobacillus helveticus MB2-1 & $\begin{array}{l}\text { Glucose, mannose, galactose, } \\
\text { rhamnose, arabinose }\end{array}$ & $1.83 \times 10^{5} \mathrm{Da}$ & [77] \\
\hline Lactobacillus kefiranofaciens WT-2B & Kefiran: glucose, galactose & $7.6 \times 10^{5} \mathrm{Da}$ & [78] \\
\hline Lactobacillus johnsonii 142 & D-glucose and D-dalactose & $1.0 \times 10^{5} \mathrm{Da}$ & [79] \\
\hline $\begin{array}{l}\text { Latilactobacillus sakei O-1 (formerly } \\
\text { Lactobacillus sakei) }\end{array}$ & Glucose, rhamnose & $6 \times 10^{6} \mathrm{Da}$ & [80] \\
\hline $\begin{array}{c}\text { Lactiplantibacillus plantarum } \\
\text { (formerly Lactobacillus plantarum) } \\
\text { JLK0142 }\end{array}$ & Glucose, galactose & $1.34 \times 10^{5} \mathrm{Da}$ & [81] \\
\hline $\begin{array}{l}\text { Lactiplantibacillus plantarum } \\
\text { WLPL04 }\end{array}$ & Xylose, glucose, galactose & $6.61 \times 10^{4} \mathrm{Da}$ & [82] \\
\hline Lactiplantibacillus plantarum YW11 & Glucose, galactose & $1.1 \times 10^{5} \mathrm{Da}$ & {$[83]$} \\
\hline $\begin{array}{l}\text { Lactiplantibacillus plantarum } \\
\text { JLAU103 }\end{array}$ & $\begin{array}{l}\text { Arabinose, rhamnose, fucose, xylose, mannose, } \\
\text { fructose, galactose, glucose }\end{array}$ & $12.4 \mathrm{kDa}$ & [84] \\
\hline Lactiplantibacillus plantarum EP56 & Glucose, galactose, rhamnose & $8.5 \times 10^{5} \mathrm{Da}$ & {$[85]$} \\
\hline Lactiplantibacillus plantarum C88 & Glucose, galactose & $1.2 \times 10^{6} \mathrm{Da}$ & [86] \\
\hline Lactiplantibacillus plantarum C70 & Arabinose, mannose, glucose, galactose & $3.8 \times 10^{5} \mathrm{Da}$ & [87] \\
\hline
\end{tabular}

\section{EPS Biosynthesis}

Regardless of their different structures, the biosynthetic pathways of EPS are remarkably similar between different species of microorganisms [88-90]. It is known that HoPS are synthesized by only one enzyme encoded by one gene. In contrast, the genetic sequence of HePS encodes multiple glycosyltransferases, polymerization proteins, and regulatory 
proteins $[90,91]$. From a biochemical point of view, there are two major groups of enzymes involved in the production of EPS. The first group consists of enzymes necessary for the synthesis of basic sugar nucleotides used by other cellular metabolic pathways [92,93]. The second group consists of EPS-specific enzymes, such as glycosyl- and acetyltransferases or enzymes responsible for polymerization and export, that regulate the whole process. However, there are also some EPS-specific enzymes whose function is not yet known [92,94]. EPS-specific enzymes are regulated by genes that are usually arranged in clusters on chromosomes or plasmids $[55,95,96]$. The biosynthesis of HoPS is a relatively simple process because there are no active transport steps and no unnecessary energy is consumed except for the biosynthesis of the extracellular enzymes. Therefore, HoPS is usually synthesized extracellularly mainly from sucrose, although recent reports describe the use of maltodextrins and starch substrates as donors of glucosyl units by some LAB species/strains $[8,21]$. The enzyme that catalyzes the polymerization of HoPS is a glycosylhydrolase that cleaves the glycosidic bond of its substrate (sucrose) and couples the glucosyl or fructosyl units to synthesize either $\alpha$-glucans or $\beta$-fructans. The energy released by cleavage of the energetic glycosidic bond is used to transfer the monosaccharide units to the reducing end of the polymer [8,97-100]. However, $\beta$-glucans are synthesized intracellularly by a membrane-associated glucosyltransferase [19]. The process of biosynthesis of HePS is more extensive and energy-consuming. The reaction steps for the synthesis of HePS are as follows: (I) internalization of the sugar, (II) synthesis of sugar nucleotide precursors from glucose-1-phosphate and fructose-6-phosphate, which provide the energy for the polymerization reaction, (III) transport across the membrane via a flippase, and (IV) polymerization by various types of glycosyltransferases located at the cytoplasmic membrane adds the monosaccharide moiety to the reducing end of the chain [90,92,101,102]. Due to variability in composition and molecular weight, HePS exhibits large differences in their stiffness, charges, spatial arrangement, and ability to interact with proteins. The variability in composition and molecular weight also affects the physicochemical properties, such as viscosity and solubility $[8,36,103,104]$. As for the LAB production of EPS, the yield is generally higher for HoPS. Several factors can affect the yield of exopolysaccharides, such as the initial $\mathrm{pH}$, temperature, incubation time, composition of the medium, and so forth [105]. Numerous studies indicate that optimization of various conditions during the production of exopolysaccharides can lead to an increase in exopolysaccharide yield [106,107]. The production of exopolysaccharides by lactic acid bacterial strains varies from $10 \mathrm{mg} / \mathrm{L}$ to $400 \mathrm{mg} / \mathrm{L}$ if the production process is not optimized. In the case of optimization, this amount can multiply $[60,108]$.

\section{Methods of EPS Screening, Isolation and Characterization}

Despite the large number of researchers working on EPS-producing LAB, there is still insufficient information on the kinetics of EPS synthesis, where variations in production yield and EPS composition can lead to complete loss of production, as numerous variables can affect production and structure $[95,109]$. These variables include cultivation time, environmental factors, and carbon source, as they can affect the chemical composition, structure, and even biological properties of EPS [110]. In addition, each microorganism has its own requirements for its ability to produce EPS [2,6,55,111]. Applying the correct methodology for EPS screening, isolation, and purification is critical because, as mentioned previously, EPS production is strain-specific and often depends on the composition of the surrounding media and incubation conditions (e.g., temperature, humidity). A variety of methods for studying EPS produced by LAB, including screening, extraction, and assessment of composition and structure, have been developed and optimized in recent years. The screening methods to evaluate the microbial ability to produce EPS are based on the cultivation of the LAB in a medium enriched with different sugars (glucose, fructose, sucrose, galactose, or lactose). The easiest way to assess EPS production is to visually observe the phenotypic characteristics of the colonies: slimy or ropy phenotypes. The slimy phenotype is characterized by mucilaginous colonies, while the ropy phenotype is 
characterized by the formation of long filaments when an inoculation loop is lifted from the colony surface or cell pellet (Figure 1). For a more objective test, ruthenium red staining is used in milk agar plates and produces red colonies of non-ropy EPS producers, while ropy colonies remain white [112].

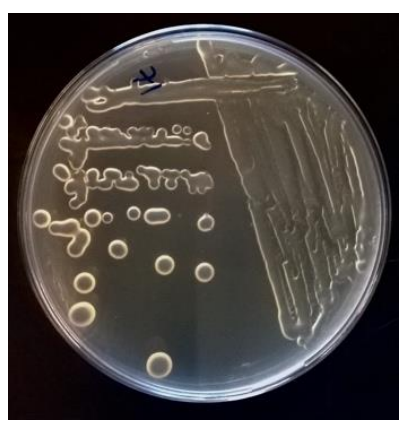

(a)

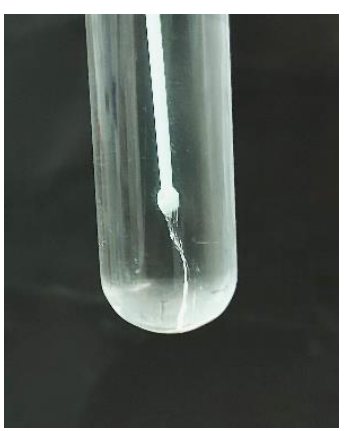

(b)

Figure 1. Characteristics of EPS produced by LAB: (a) Mucoid colonies-slimy phenotype; (b) Ropy phenotype.

Qualitative methods, such as confocal laser scanning microscopy (CLSM) and electron microscopy (EM), are usually used for the detection of EPS in food. CLSM is used to study the presence and distribution of fluorescently labeled EPS in food matrices and has the advantage of visualizing changes in food microstructures without the need for sample preparation [74]. In contrast, EM requires high vacuum conditions and dehydration of the sample. However, EM is useful to determine the structural features at nanometer scale due to the high resolution of the images produced [74].

Quantitative evaluation of EPS produced by LAB requires extraction from the culture media or food matrices. Extraction of EPS involves several steps, including centrifugation to recover the EPS-containing supernatant, addition of acid (e.g., TCA) to remove the high protein content, and precipitation with cold ethanol (Figure 2). The precipitated EPS is then collected and dissolved in water before membrane filtration (usually dialysis or ultrafiltration) to remove the small neutral sugars, salts, and small proteins [19,113-116]. Finally, the dialyzed EPS solution is freeze-dried to obtain a pure EPS solid, which has a white color and a soft, spongy texture (Figure 2). In this step, the weight of the obtained EPS gives an approximate indication of the EPS yield [117]. Colorimetric methods such as the phenol-sulfuric acid method [118] or the sulfuric acid-UV method, which is more accurate and faster, are usually used to quantify the EPS [119]. Sometimes a second purification step is required to ensure the high purity of EPS [110]. This may involve treatment with proteases and nucleases to remove contaminating proteins and DNA. In addition, anion exchange chromatography and/or size exclusion chromatography are recommended as they contribute to high-purity samples [120]. The number of steps used for EPS isolation depends on the complexity of the media used for production and the type of EPS (HoPS or HePS). Therefore, a prior study is essential to optimize and improve the fermentation conditions.

A complete description of the structural features of EPS includes the identification of monosaccharide composition, ring conformation, linkage, degree of branching, and molecular weight. Several methods have been used to identify and analyze EPS molecular weight, composition, and structure. No single method is capable of assigning all of these parameters, so a combination of several techniques is usually required. Among the most commonly used methods for the determination of EPS molecular mass are size exclusion chromatography (SEC) and ion exclusion chromatography (IEC) [74]. To evaluate the monomer composition, the glycosidic bonds must be previously hydrolyzed by acids or enzymes, and the released monomers are then subjected to high-performance liquid chromatography (HPLC) with refractive index detection (HPLC-RI), high-performance ion 
exchange chromatography (HPAEC) with pulse amperometric detection (HPAEC-PAD), or gas chromatography [1] coupled with mass spectrometry (GC-MS) [121]. The properties and functionality of EPS also depend on the functional groups and the nature of the bond, which can be detected by Fourier transform infrared spectroscopy (FTIR). Nuclear magnetic resonance (NMR) spectroscopy is also used to analyze the glycosidic bonds, ring configuration, and anomeric configuration of the monomeric units [74,92,122].

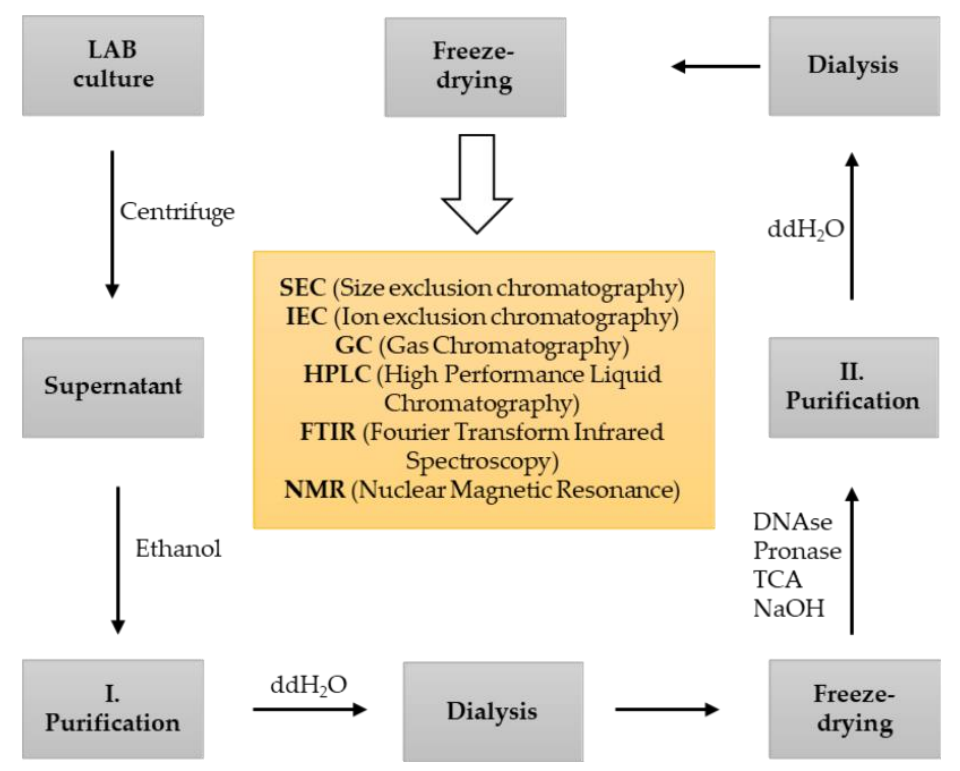

Figure 2. Flow chart for isolation, purification steps (I-first purification, II-second purification), and characterization of EPS.

\section{Application of EPS-Producing LAB in Food Products}

\subsection{Yoghurt}

EPS produced by LAB can be used to thicken and stabilize fermented dairy products. Lowering the $\mathrm{pH}$ during the fermentation process of yoghourt can lead to syneresis resulting from destabilisation of casein micelles. In situ production of EPS has been used to overcome this problem, as it leads to better rheological properties than when EPS is added as one of the components [92,123]. The starter cultures used for yoghourt production, Lactobacillus delbruecki subsp. bulgaricus and Streptococcus thermophilus, were selected to produce exopolysaccharides, generally 60-150 mg/L and 30-890 mg/L, respectively [8,124]. In recent years, studies have been conducted on new EPS-producing starter or adjunct cultures to be used in yoghourt production [8,125]. For example, Han et al. [126] evaluated 19 high EPS-producing Str. thermophilus strains isolated from traditional Chinese fermented milk products and used in yoghourt production. They selected a starter with high EPS production (SH-1), which exhibited lower syneresis, better texture, and better sensory evaluation than the samples fermented with a commercial yoghourt starter culture [126]. Fermented dairy products with low fat content can also be improved by using starters with high EPS production, as milk fat plays an important role on the taste, texture, and overall rheological properties of these products [127]. For example, the performance of EPS-producing Limosilactobacillus mucosae (formerly Lactobacillus mucosae) DPC 6426 as an adjunct culture in the production of low-fat yoghourt has been evaluated and shown to reduce syneresis and improve the functional properties of yoghourt [128].

\subsection{Cheese}

A variety of LAB cultures are used in cheese-making as starters and/or adjunct cultures [129]. Nowadays, customers are looking for healthier, low-fat cheeses, and this is where bacterial strains that can produce EPS come into play. As with any other dairy 
product, the amount of fat is critical to the texture and flavor of the cheese. Therefore, EPS produced by starter/adjuvant cultures can be used as a fat substitute and texturizer in the production of low-fat cheese [8]. Several studies have shown that EPS improves the texture and quality of low-fat cheese, resulting in a product that has similar properties to its full-fat counterpart. For example, EPS-producing strains of the genus Lactobacillus have been shown to increase moisture content and improve the melting of low-fat mozzarella cheese $[8,130]$. In a study by Costa et al. [131], an EPS-producing strain of Lactococcus lactis was used on semi-fat cheddar cheese. Several positive effects of the exopolysaccharide were observed, such as an increase in cheese yield. There was no negative interaction between the starter strain or the ripening strain and the exopolysaccharide-producing strain. After 3 months of ripening, some tests showed that the addition of the EPS-producing strain resulted in a semi-fat cheddar cheese with similar characteristics to a full-fat cheddar cheese without any change in taste [131]. For low-fat cheddar cheese, the addition of the EPS-producing culture of $L b$. plantarum resulted in cheeses with higher moisture content, higher proteolysis and better sensory values, as well as lower hardness and cohesion compared to the control cheese [132]. In addition, the use of a mixed starter culture containing EPS-producing strains in the production of low-fat Kasar cheese improved the textural properties by producing a less compact protein matrix and a spongy structure [133]. The type of EPS was also shown to affect the rheological properties of the cheese. It was shown that the lower branching ropy EPS reduced protein particle size and decreased creaminess in a model of a low-fat fresh cheese, while the capsular EPS mainly contributed to the reduction of syneresis [134]. The use of EPS-producing LAB in full-fat cheeses has also been studied by several authors. In the production of Prato cheese, the use of exopolysaccharide-producing cultures was shown to improve yield and increase moisture content without affecting proteolysis, pH, melting ability, and sensory acceptability [135]. Rehman et al. [136] used a high EPS-producing strain of Lactobacillus kefiranofaciens isolated from Tibetan kefir grain to improve the chewiness and hardness of mozzarella cheese. In a recent study, in situ production of EPS was used to improve the production yield and rheological properties (hardness, elasticity and adhesiveness) of sour whey cheese-requesón [137].

\subsection{Kefir}

Kefir is a self-carbonated, slightly alcoholic beverage made from fermented milk, traditionally from Eastern Europe. Kefir preparation requires kefir grains, which are composed of proteins and polysaccharides and contain a symbiotic association of homofermentative and heterofermentative lactic acid bacteria, acetic acid bacteria, and yeasts [127]. During the fermentation process, exopolysaccharides known as kefiran are produced and act as viscosity regulators. Kefiran is a branched water-soluble glucogalactan composed of equal parts glucose and galactose, and its production is mainly due to Lactobacillus kefiranofaciens $[8,127]$. Within the complex community of kefir grains, other species of LAB have been isolated from kefir and found to produce EPS, such as Lactiplantibacillus plantarum, Lacticaseibacillus paracasei, Lactobacillus helveticus, Lactiplantibacillus pentosus, Lactococcus lactis subsp. Lactis, and Leuconostoc mesenteroides [138-141]. In the last decade, selected strains of mesophilic LAB have been investigated for their ability to ferment milk and produce EPS to improve the rheological properties of fermented milk-based foods [83,138,139,142]. In addition, much attention has also been paid to non-dairy products fermented with kefir grains. Due to the wide variety of sugars and subtracts used in the fermentation process, the microbial diversity of non-dairy kefir grains may be greater than that of traditional kefir grains. Several authors reported 45 different bacterial species and 23 yeasts [143]. However, due to its great complexity, the relative composition of bacteria and yeasts may vary during the kefir fermentation process, making it difficult to control and obtain uniform products for industrial use [143]. 


\subsection{Application of EPS-Producing LAB in Plant-Based Beverages}

In recent years, interest in vegetarian and vegan diets has increased for many reasons (e.g., health concerns, ethical concerns, sustainability). The challenge for manufacturers of plant-based milk alternatives is to produce products with acceptable taste and texture for customers [92,144]. The application of EPS-producing LAB has emerged to improve the sensory and organoleptic analysis of such products, as EPS can positively influence texture, mouthfeel, and syneresis [92,145]. Several studies have focused on the use of in situ production of EPS in fermented plant-based beverages, as it is possible to develop a large number of products with improved sensory properties. Li et al. [14] studied the fermentation process of soy milk with an EPS-producing L. plantarum strain over a period of 21 days. The fermented soy milk maintained the apparent viscosity and EPS content, exhibited satisfactory technological properties, and improved the taste of soy milk [14]. In another study, Hickisch et al. [144] attempted to produce a vegetable yoghourt alternative from lupins, which proved to be a good plant choice. A different strain of EPSproducing Lactiplantibacillus plantarum (TMW 1.460) was used for the fermentation process, which achieved better sensory values, such as appearance, texture, aroma, and taste [144]. Beverages mimicking the characteristics of cow's milk yoghourt were also developed using an aqueous extract of quinoa flour and Weissella spp. as EPS producers and showed high acceptability in terms of acidity, sweetness, texture, and overall appearance [146,147].

\subsection{Application of EPS in Bakery}

EPS produced by LAB has been proposed as a promising alternative to replace the use of polysaccharides in bakeries as an additive for sourdough because they have thickening properties. EPS-producing LAB can be incorporated into fermented sourdough to have a positive effect on the techno-functional properties of baked goods [148-150]. The in situ production of EPS has been shown to improve the handling and stability of the dough, but also to increase the technological properties of the final product, such as the texture and volume of the bread $[150,151]$. Moreover, the use of selected EPS-producing LAB strains in sourdoughs has been investigated as a novel technological approach to compensate for quality losses in the functional properties of reduced-sugar products or to replace the added fat in bakery products $[149,152]$. In addition, some studies have shown that the use of EPS-producing LAB has a cold-protective effect and overcomes the quality loss of frozen dough products [153]. The use of polysaccharides has gained interest in recent years with the increasing production of gluten-free products. Not only are customers looking for healthier products, but people with a chronic autoimmune disease-celiac disease-are also looking to bakeries for better-quality gluten-free products $[8,92,154]$. The beneficial effect of EPS produced by LAB is to improve the structure and volume of gluten-free or glutencontaining bread, as they are able to bind water and form a high-quality network with other dough components. This later leads to softer bread crumb and longer shelf life [10,155]. The in situ production of EPS was demonstrated in a recent study by Zheng et al. [45], in which the EPS-producing Limosilactobacillus reuteri was used during the fermentation process. Its ability to produce fructans and glucans resulted in better-quality gluten-free bread.

\subsection{Application of EPS in Meat Industry}

While EPS-producing LAB are widely used in the dairy industry, their use in the meat industry is still a relatively new area of research [74]. Meat production dates back many millennia, and the use of lactic acid bacteria has given us an enormous variety of traditional foods around the world. By producing lactic acid or acetic acid in raw meat, we can control food safety, texture, color of meat, and much more $[92,94]$. Meat products contain many important nutrients (protein, iron, zinc, vitamins, etc.), but consumption of high-fat meat products may correlate with diseases such as diabetes or cardiovascular disease. Customer demand for low-fat meat products challenges the meat industry to develop new products to serve this market. This poses many problems for the meat industry because low-fat processed meat products may be deficient in terms of technological and 
sensory properties $[74,92,94,156]$. Hydrocolloids are widely used as food additives in the food industry. In the meat industry, they are known to improve the water-holding capacity and gelling properties of meat proteins and can improve the texture of low-fat meat products, but nowadays customers reject food additives on the ingredient list [157-160]. Therefore, in situ production of EPS by LAB during meat processing could be an interesting alternative. Few studies have been conducted on the in situ production of EPS by LAB in meat products. Meat products evaluated for the use of LAB for in situ production of EPS included cooked ham, raw fermented sausages (sucuk and salami), and spreadable raw fermented sausages [74]. Although the processing conditions for ham production showed a negative effect on EPS production, the use of in situ EPS-forming LAB was more promising for the production of fermented sausages [74,161]. In the study by Hilbig et al. [46], selected LAB strains (L. plantarum and L. curvatus strains) were able to produce sufficient amounts of EPS during sausage fermentation to allow reduction of the high fat content of fermented raw sausages [46]. Moreover, Dertli et al. [162] used EPS-forming LAB cultures in a Turkish fermented sausage to improve its textural properties, which became harder, less sticky, and tougher.

\section{Health-Promoting Effects}

Several pieces of evidence have shown that EPS produced by LAB are associated with numerous functional roles and health benefits, such as immunomodulatory, antioxidant, anticancer, antiulcer, anti-biofilm, and cholesterol-binding effects [5,20,163-169]. However, it has been found that the biological activity of different EPS is influenced by their chemical structure (main chain, branching and molecular weight) [170,171]. Fermented foods can provide LAB-derived EPSs with prebiotic properties that promote colonization of the gut with beneficial bacteria $[90,172,173]$. One of the beneficial capabilities of probiotic bacteria is the formation of biofilms that support their colonization and maintenance of their population in the harsh conditions of the human gastrointestinal tract (GIT) [174]. Thus, attachment of probiotic LAB to epithelial cells in the GIT has been shown to prevent colonization by pathogenic organisms, stimulate the host immune system, and protect epithelial cells from toxic compounds (e.g., carcinogens and toxic metal ions) [102,175]. In addition, LAB-derived EPS can reduce or inhibit biofilm formation by pathogenic bacteria, thereby preventing infectious diseases $[175,176]$. Other studies have shown that these EPS have the potential to affect the gastrointestinal tract by protecting intestinal cells from toxins and lowering cholesterol levels through increased secretion of bile acids $[165,168,177]$.

The multiple functional activities of LAB-produced EPSs are also very useful and find application in therapeutic medicine as drug carriers and in adjuvant therapy for the treatment of inflammation and cancer due to their high ability to form hydrogels [92,178-183]. For example, Moscovici [184] attempted to incorporate biomolecules and therapeutics into the internal structure of EPS for use as an intelligent drug delivery system for the treatment of brain tumors or other neurological diseases due to their biocompatibility and apparent lack of toxicity. Most studies on the health benefits of EPS have been conducted in vitro, and there is limited information on in vivo experiments with oral administration [167]. However, as new EPS and EPS-producing LAB have been identified, there are emerging studies that provide positive evidence for the use of EPS in medicine and functional foods (Figure 3).

\subsection{Prebiotic Activity}

Although a growing number of studies confirm the health-promoting effects of EPS, no mechanism of action has yet been proposed that clearly explains how they can exert such activities on biological tissues $[168,185]$. However, some authors propose that EPSs remain longer in the gastrointestinal tract to exert their effects as prebiotics. Since EPSs are not degraded by human digestive enzymes, they can exert their prebiotic effect and promote colonization by probiotic bacteria, such as lactobacilli and bifidobacteria $[20,169,186]$. For example, Abedfar et al. [187] found that symptoms of lactose intolerance decreased with 
the presence of EPS in the gastrointestinal tract, which was attributed to the proliferation of lactase-producing lactobacilli. Hamdy et al. [188] evaluated the prebiotic activity of EPS in a rat model over 60 days and found an increase in Lactobacillus counts while Escherichia coli counts decreased, confirming that the increase in beneficial bacteria was related to the presence of EPS. Recently, Pan et al. [189] reported the modulation of the gut microbiota of mice by feeding a linear dextran produced by a strain of Leuconostoc pseudomesenteroides. EPS altered the structure of the gut microbiota and decreased the ratio of Bacteroidetes to Firmicutes in treated mice.

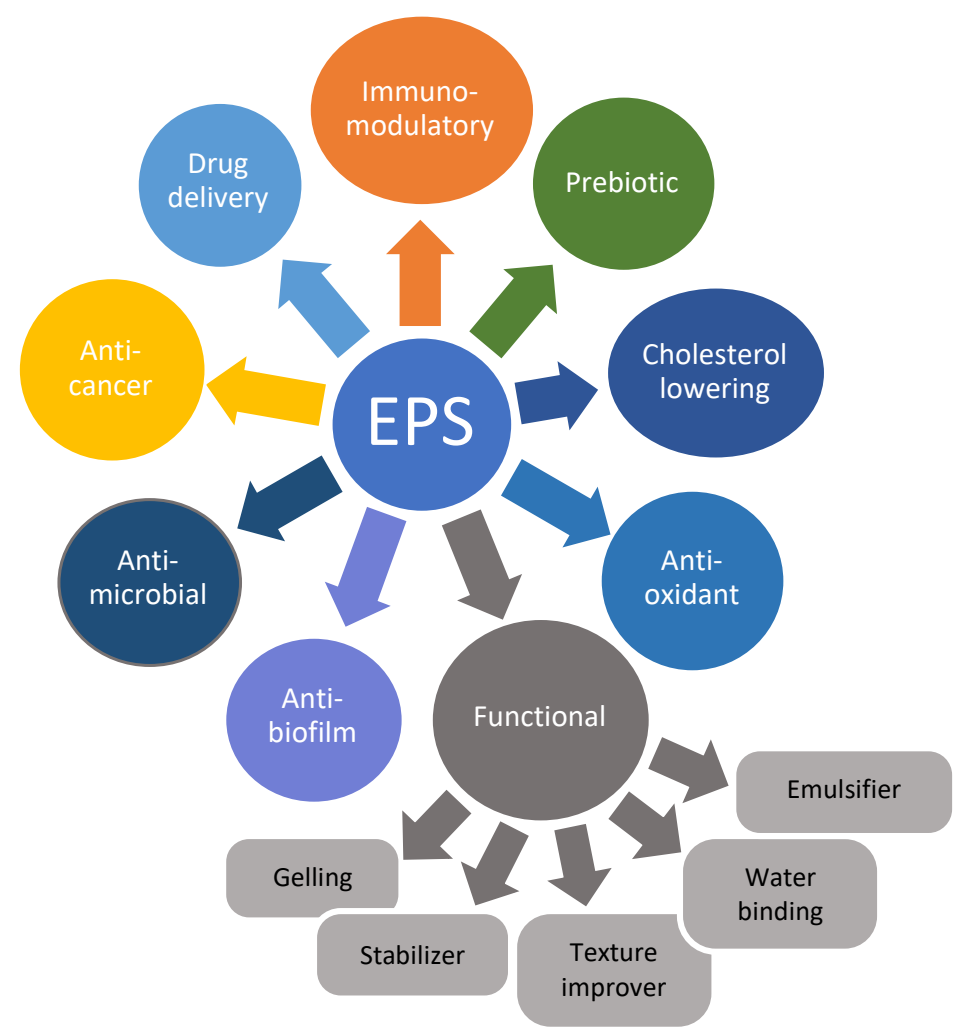

Figure 3. Biological and functional activities exerted by EPS produced by LAB.

\subsection{Immunomodulatory Activity}

Many food components (called immunomodulators) are known to modulate the innate and adaptive immune system. EPSs, proteins, peptides, glycoproteins, lipopolysaccharides and others are among the many molecules that have immunomodulatory properties. These immunomodulators alter the activity of immune function by regulating cytokines and are able to suppress infections and prevent immunodeficiency-related diseases (e.g., inflammatory bowel disease) of the gastrointestinal tract [168,171,190-192]. Acidic HePS, characterized by having phosphate (i.e., a negative charge) in their position, seem to be well-able to trigger the immune response [193]. This has been confirmed by studies showing that phosphate is the molecule that triggers the immune response, as chemical dephosphorylation of these HePS leads to a decrease in the stimulatory effect $[168,171,190,194,195]$. However, immunomodulatory activity has also been associated with high molecular weight HePS, which appears to suppress the immune response [168,171,185,190,196-198]. In addition, the monosaccharide composition of EPS has been shown to influence its anti-inflammatory properties, possibly by association with the recognition of receptors on the surface of immune cells $[199,200]$. Several studies have shown that EPS produced by LAB stimulates the production of cytokines and antigen-presenting cells [201,202]. Dilna et al. [203] reported the promoting effect of EPS produced by L. plantarum on the production of cytokines by macrophages, especially tumor necrosis factor $\alpha$ (TNF- $\alpha$ ), interleukin 6 (IL -6), IL -1b and IL -12. In a particular study, $(1 \rightarrow 6)-\alpha$-D-glucan with low Mw from Lactobacillus confusus 
was shown to modulate the immune system to produce the pro-inflammatory mediator nitric oxide (NO) and cytokines [195]. In a rat-induced allergic asthma model using ovalbumin (OVA), Domingos-Lopes et al. [204] demonstrated that the orally administered EPS producer Leuconostoc citreum induced immune tolerance to the allergen OVA, specifically by downregulating the overproduction of IgE and reducing the Th2-mediated allergic response. Moreover, in a study using a similar mouse model of respiratory allergy, intranasal administration of EPS from Bifidobacterium longum was shown to reduce the recruitment of eosinophils in the lungs [205]. In a similar study, EPS from L. rhamnosus was also shown to effectively control T-cell-dependent immune responses in various inflammatory diseases [206].

Other studies also demonstrated the important role of EPS in maintaining the balance of the immune system during infection or inflammation [185]. In the study by Matsuzaki et al. [207], it was shown that the EPS-producing Leuconostoc mesenteroides strain could induce the secretion of immunoglobulin A ( $\operatorname{Ig} A)$, indicating a potential use against mucosal pathogens.

\subsection{Antioxidant Activity}

The accumulation of reactive oxygen species (ROS) leads to oxidative stress in living organisms, which damages biological macromolecules such as DNA, RNA, proteins, and lipids, and can result in tissue damage that can later lead to the development or progression of various diseases (obesity, cancer, neurodegenerative disorders, etc.) [168,171,196,203,208,209]. Exogenous regulation with natural antioxidants (ascorbic acid, $\alpha$-tocopherol and carotenoids) has been proposed as a way to reduce oxidative stress and delay oxidative damage. Therefore, EPS derived from LAB can be considered as effective natural antioxidants for preventing oxidative stress caused by free radicals. There are numerous studies reporting the antioxidant activity of EPSs produced by LAB, which were evaluated based on their ability to scavenge superoxide anions and hydroxyl radicals [210]. A recent study by Liu et al. [211] reported that sulfonation of EPS produced by Lactiplantibacillus plantarum increased antioxidant activity, thereby protecting epithelial cells.

\subsection{Cholesterol Lowering Abilities}

Major risk factors for cardiovascular disease include high blood pressure and elevated blood cholesterol. There are a growing number of studies showing the ability of EPS from LAB to regulate serum cholesterol levels through intestinal adsorption of this molecule [185]. In this sense, Soh et al. [212] showed the adsorption of cholesterol through an in vitro enzymatic reaction and a polysaccharide precipitation process. Studies in animals and humans have also shown the effect of LAB-derived EPS in lowering blood cholesterol levels. For example, Dilna et al. [203] showed that EPS isolated from L. plantarum RJF4 had a cholesterol-lowering effect. In another study, mucilage EPS produced by L. lactis subsp. cremoris was shown to have a beneficial effect on cholesterol metabolism in rats by lowering serum cholesterol levels [213]. In a similar study, Ai et al. [214] showed that EPS has an antihypertensive effect in an in vivo rat model.

\subsection{Anti-Biofilm Formation}

Many bacterial species, including pathogenic bacteria, become more resistant to extracellular stress conditions by building biofilms [174]. Biofilms are arrays of bacterial cells bound to a surface in an extracellular polymer matrix composed of EPS, proteins, and extracellular DNA [176]. Biofilms formed by pathogenic bacteria can cause many problems, such as food safety issues or ineffective treatment of infectious diseases $[168,215,216]$.

Several authors reported the potential of LAB -derived EPS to reduce or prevent the formation of biofilms by pathogenic bacteria and thereby control infections caused by the pathogens [176]. For example, an HePS composed of mannose, glucose and galactose was shown to have considerable anti-biofilm activity against six bacterial pathogens [217]. Several authors have proposed different mechanisms by which EPS can inhibit biofilm 
formation. Lynch et al. [10] hypothesized that EPS may mask adhesion molecules in the intestinal mucus, thus preventing adhesion of other bacteria. On the other hand, Abdalla et al. [176] proposed that biofilms produced by LAB promote their own colonization in the host mucosa, thus inhibiting the formation of biofilms by bacterial pathogens.

\subsection{Antimicrobial Activity}

In recent years, antimicrobial resistance has become a very serious health problem, increasing the demand for new antimicrobial drugs. Several authors have shown that LAB -derived EPSs can exhibit antagonistic effects in vitro against Gramme-positive and Gramme-negative pathogens or against pathogenic bacteria in the gastrointestinal tract $[47,176,218]$. For example, HePS produced by Lactobacillus gasseri inhibited in vitro antibacterial activity against several foodborne pathogens such as Escherichia coli, Listeria monocytogenes and Staphylococcus aureus [76]. The EPS produced by a Lactobacillus strain also showed considerable antibacterial activity against the pathogenic bacteria Salmonella enterica and Micrococcus luteus [219]. In a similar study, HePS isolated from L. kefiranofaciens was shown to exert bactericidal activity against Listeria monocytogenes and Salmonella enteritidis [220]. In another study, silver nanoparticles with EPS produced by LAB were used against pathogenic bacteria. These were found to have antimicrobial activity against Gramme-positive and Gramme-negative bacteria, with Gramme-positive bacteria being more sensitive [221]. The antimicrobial activity of EPSs in vivo can also be explained by the prebiotic effect that helps probiotics to colonise the surface of the gastrointestinal tract, thus enhancing their competitive inhibition of pathogenic bacteria in the host [90]. Recent studies showed remarkable antifungal activity of some EPS produced by Lactobacillus strains [176]. Moreover, Álvarez et al. [222] used the strain L. plantarum for the production of EPSs included in an edible coating as an antifungal agent. EPSs have also been reported to exert antiviral activities, especially the sulfated EPSs [90]. It is believed that the immunomodulatory effect of EPSs produced by LAB is responsible for the antiviral activity [176,182]. In a study by Nagai et al. [223], EPS produced by Lactobacillus bulgaricus in fermented yoghourt was fed to mice infected with influenza virus. They found an increase in natural killer cell activity and an increase in immunoglobulins IgG1 and IgA, which led to a reduction in viral infection.

\subsection{Anti-Cancer Activity}

Cancer is an abnormal form of tissue growth due to irreversible damage to DNA caused by mutations in certain proto-oncogenes and tumor suppressor genes, resulting in a progressive increase in the number of dividing cells. Highly effective chemotherapies are cytotoxic/immunotoxic, which affects tumor development and impairs patient recovery $[168,224]$. The discovery and identification of new antitumor drugs with low side effects on the immune system has become an important goal in many immunopharmacology studies. EPS from safe natural sources such as LAB usually have low cytotoxicity and side effects and can serve as good substitutes for synthetic antitumor agents [196,216,224]. Liu et al. [202] demonstrated the antiproliferative effect of L. casei EPS on HT -29 cell line. Al-so, the EPS produced by L. plantarum strain showed remarkable antitumor activity on HepG-2, BGC-823 and especially HT -29 cancer cells [216]. EPS produced by L. casei, L. plantarum and L. acidophilus showed antitumor properties against different cell lines depending on the dose [225]. Self-assembled nanoparticles from EPS loaded with anticancer drugs, such as epirubicin, increase the uptake of the drug in mice bearing tumors while decreasing the uptake in heart and kidney. They show a sustained release pattern and a $70 \%$ reduction in tumor volume [226]. Another study by Liu et al. [208] showed the antioxidant and antiproliferative effects of EPS produced by LAB on hepatoma cells, HepG2.

\subsection{Drug Delivery Systems}

EPSs are promising candidates for drug delivery systems due to their bioactive function and ability to transport drugs. Bacterial EPSs not only serve as bioactive agents but can 
also be potential carriers for valuable drugs, including growth factors and antitumor agents. Although their function as carriers is similar, the production of EPSs as drug carriers is simpler than the production of biological scaffolds loaded with viable cells. As drug carriers, EPS can be modified to facilitate the controlled release of drugs, increase the shelf life of drugs in the body, and improve drug efficacy. Antibiotics are often used as a model for drug release by bacterial EPS [168,227,228]. In a study by Wang et al. [229], it was reported that encapsulation with kefiran was able to protect ciprofloxacin from gastric conditions. In another study, sulfated EPS of bacterial origin were used as vaccine adjuvants for the treatment and prevention of hepatitis B virus in animal models [230].

\section{Conclusions}

The diversity of EPS produced by LAB has increased and become the focus of many researchers in recent years. The non-toxic behavior of EPSs offers tremendous opportunities for applications in food, medicine, and even pharmaceuticals. LAB -derived EPSs hold remarkable properties, improving stability, flavor, texture, shelf life, and rheological properties of several food products. In addition to technological benefits, recent research shows the health benefits of EPSs, such as immunomodulatory, antioxidant, prebiotic, antibiofilm, cholesterol-lowering, antimicrobial, and anticancer activities. Therefore, the use of LAB cultures for in situ production of EPS meets the consumer demand for health-promoting functional foods. The major limitation for the industrial use of EPS is the low yield and wide variation in the production capacity of EPS-producing strains. Therefore, it is crucial to explore new ideas to optimize the production of EPS for its future industrial use. The type of EPS (HoEPS or HeEPS), molecular weight, monosaccharide composition, and functional groups are also crucial factors affecting technological and biological activities. Most of the research conducted in recent years has focused on the evaluation of EPS structures as well as novel functionalities. However, the mechanisms by which EPSs exert their effects in biofilm formation, immune system modulation, and pathogen inhibition are very complex and still not fully understood. A better understanding of the underlying mechanisms could lead to the development of tailored EPSs with desired/specific properties for use in functional foods or as therapeutic agents.

Author Contributions: Draft preparation: D.J. and C.C.G.S.; writing: D.J.; tables and figures preparation, D.J.; review and editing, D.J., S.C.R. and C.C.G.S.; supervision, S.C.R. and C.C.G.S. All authors have read and agreed to the published version of the manuscript.

Funding: This work was financially supported by Portuguese Foundation for Science and TechnologyFCT, Project UIDB/00153/2020. D. Jurášková is thankful to Fundação para a Ciência e Tecnologia (FCT) for Ph.D. scholarship UI/BD/151108/2021. S.C. Ribeiro is thankful to the Regional Science and Technology Fund (FRCT) for financial support-grant M3.1.a/F/017/2018.

Institutional Review Board Statement: Not applicable.

Informed Consent Statement: Not applicable.

Data Availability Statement: Not applicable.

Acknowledgments: The authors are thankful to Institute of Agricultural and Environmental Research and Technology (IITAA), University of the Azores.

Conflicts of Interest: The authors declare no conflict of interest.

\section{References}

1. Manjanna, K.M.; Shivakumar, B.; Pramodkumar, T.M. Natural exopolysaccharides as novel excipients in drug delivery: A Review. Arch. Appl. Sci. Res. 2009, 1, 230-253.

2. Welman, A.D.; Maddox, I.S. Exopolysaccharides from lactic acid bacteria: Perspectives and challenges. Trends Biotechnol. 2003, 21, 269-274. [CrossRef]

3. Górska, S.; Grycko, P.; Rybka, J.; Gamian, A. Egzopolisacharydy bakterii kwasu mlekowego—Biosynteza i struktura. Exopolysaccharides of Lactic Acid Bacteria: Structure and Biosynthesis. Postepy Hig. Med. Dosw. Online 2007, 61, 805-818. [PubMed] 
4. Harapanahalli, A.K.; Younes, J.A.; Allan, E.; van der Mei, H.C.; Busscher, H.J. Chemical signals and mechanosensing in bacterial responses to their environment. PLoS Pathog. 2015, 11, e1005057. [CrossRef]

5. Oleksy, M.; Klewicka, E. Exopolysaccharides produced by Lactobacillus sp.: Biosynthesis and applications. Crit. Rev. Food Sci. Nutr. 2018, 58, 450-462.

6. Oleksy-Sobczak, M.; Klewicka, E.; Piekarska-Radzik, L. Exopolysaccharides production by Lactobacillus rhamnosus strainsOptimization of synthesis and extraction conditions. LWT 2020, 122, 109055. [CrossRef]

7. Ullrich, M. Bacterial Polysaccharides: Current Innovations and Future Trends; Horizon Scientific Press: Poole, UK, 2009; ISBN 1-904455-45-X.

8. Daba, G.M.; Elnahas, M.O.; Elkhateeb, W.A. Contributions of exopolysaccharides from lactic acid bacteria as biotechnological tools in food, pharmaceutical, and medical applications. Int. J. Biol. Macromol. 2021, 173, 79-89. [CrossRef] [PubMed]

9. Mishra, A.; Jha, B. Microbial Exopolysaccharides. In The Prokaryotes: Applied Bacteriology and Biotechnology; Springer: Berlin/Heidelberg, Germany, 2013; pp. 179-192. ISBN 978-3-642-31331-8.

10. Lynch, K.M.; Coffey, A.; Arendt, E.K. Exopolysaccharide producing lactic acid bacteria: Their techno-functional role and potential application in gluten-free bread products. Food Res. Int. 2018, 110, 52-61. [CrossRef]

11. Amiri, S.; Rezaei Mokarram, R.; Sowti Khiabani, M.; Rezazadeh Bari, M.; Alizadeh Khaledabad, M. Exopolysaccharides production by Lactobacillus acidophilus LA5 and Bifidobacterium animalis subsp. lactis BB12: Optimization of fermentation variables and characterization of structure and bioactivities. Int. J. Biol. Macromol. 2019, 123, 752-765. [CrossRef]

12. Caggianiello, G.; Kleerebezem, M.; Spano, G. Exopolysaccharides produced by lactic acid bacteria: From health-promoting benefits to stress tolerance mechanisms. Appl. Microbiol. Biotechnol. 2016, 100, 3877-3886. [CrossRef]

13. Kšonžeková, P.; Bystrický, P.; Vlčková, S.; Pätoprstý, V.; Pulzová, L.; Mudroňová, D.; Kubašková, T.; Csank, T.; Tkáčiková, L' Exopolysaccharides of Lactobacillus reuteri: Their influence on adherence of E. coli to epithelial cells and inflammatory response. Carbohydr. Polym. 2016, 141, 10-19. [CrossRef]

14. Li, C.; Li, W.; Chen, X.; Feng, M.; Rui, X.; Jiang, M.; Dong, M. Microbiological, physicochemical and rheological properties of fermented soymilk produced with exopolysaccharide (eps) producing lactic acid bacteria strains. LWT Food Sci. Technol. 2014, 57, 477-485. [CrossRef]

15. Ren, W.; Xia, Y.; Wang, G.; Zhang, H.; Zhu, S.; Ai, L. Bioactive exopolysaccharides from a S. thermophilus strain: Screening, purification and characterization. Int. J. Biol. Macromol. 2016, 86, 402-407. [CrossRef]

16. Hussain, A.; Zia, K.M.; Tabasum, S.; Noreen, A.; Ali, M.; Iqbal, R.; Zuber, M. Blends and composites of exopolysaccharides; properties and applications: A review. Int. J. Biol. Macromol. 2017, 94, 10-27. [CrossRef] [PubMed]

17. Sutherland, I.W. Microbial polysaccharides from gram-negative bacteria. Int. Dairy J. 2001, 11, 663-674. [CrossRef]

18. Vanhaverbeke, C.; Heyraud, A.; Mazeau, K. Conformational Analysis of the exopolysaccharide from Burkholderia caribensis strain MWAP71: Impact on the interaction with soils. Biopolym. Orig. Res. Biomol. 2003, 69, 480-497.

19. Torino, M.I.; Font de Valdez, G.; Mozzi, F. Biopolymers from lactic acid bacteria. Novel applications in foods and beverages. Front. Microbiol. 2015, 6, 834. [CrossRef]

20. Patel, S.; Majumder, A.; Goyal, A. Potentials of exopolysaccharides from lactic acid bacteria. Indian J. Microbiol. 2012, 52, 3-12 [CrossRef]

21. Gangoiti, J.; Pijning, T.; Dijkhuizen, L. Biotechnological potential of novel glycoside hydrolase family 70 enzymes synthesizing

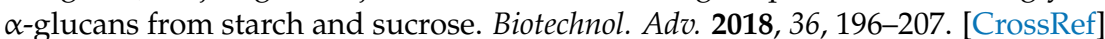

22. Aburas, H.; İspirli, H.; Taylan, O.; Yilmaz, M.T.; Dertli, E. Structural and physicochemical characterisation and antioxidant activity of an $\alpha$-D-Glucan produced by sourdough isolate Weissella cibaria MED17. Int. J. Biol. Macromol. 2020, 161, 648-655. [CrossRef] [PubMed]

23. Chen, Z.; Ni, D.; Zhang, W.; Stressler, T.; Mu, W. Lactic acid bacteria-derived $\alpha$-Glucans: From enzymatic synthesis to miscellaneous applications. Biotechnol. Adv. 2021, 47, 107708. [CrossRef] [PubMed]

24. Van Leeuwen, S.S.; Kralj, S.; van Geel-Schutten, I.H.; Gerwig, G.J.; Dijkhuizen, L.; Kamerling, J.P. Structural analysis of the $\alpha$-D-Glucan (EPS180) produced by the Lactobacillus reuteri strain 180 glucansucrase GTF180 Enzyme. Carbohydr. Res. 2008, 343, 1237-1250. [CrossRef]

25. Argüello-Morales, M.A.; Remaud-Simeon, M.; Pizzut, S.; Sarçabal, P.; Willemot, R.-M.; Monsan, P. Sequence Analysis of the gene encoding alternansucrase, a sucrose glucosyltransferase from Leuconostoc mesenteroides NRRL B-1355. FEMS Microbiol. Lett. 2000, 182, 81-85. [CrossRef]

26. Bajpai, V.K.; Majumder, R.; Rather, I.A.; Kim, K. Extraction, isolation and purification of exopolysaccharide from lactic acid bacteria using ethanol precipitation method. Bangladesh J. Pharmacol. 2016, 11, 573-576. [CrossRef]

27. Zannini, E.; Waters, D.M.; Coffey, A.; Arendt, E.K. Production, properties, and industrial food application of lactic acid bacteriaderived exopolysaccharides. Appl. Microbiol. Biotechnol. 2016, 100, 1121-1135. [CrossRef]

28. Kavitake, D.; Devi, P.B.; Singh, S.P.; Shetty, P.H. Characterization of a novel galactan produced by Weissella confusa KR780676 from an acidic fermented food. Int. J. Biol. Macromol. 2016, 86, 681-689. [CrossRef] [PubMed]

29. Maina, N.H.; Tenkanen, M.; Maaheimo, H.; Juvonen, R.; Virkki, L. NMR spectroscopic analysis of exopolysaccharides produced by Leuconostoc citreum and Weissella confusa. Carbohydr. Res. 2008, 343, 1446-1455. [CrossRef] [PubMed]

30. Bounaix, M.-S.; Gabriel, V.; Robert, H.; Morel, S.; Remaud-Siméon, M.; Gabriel, B.; Fontagné-Faucher, C. Characterization of Glucan-producing Leuconostoc strains isolated from sourdough. Int. J. Food Microbiol. 2010, 144, 1-9. [CrossRef] 
31. Chellapandian, M.; Larios, C.; Sanchez-Gonzalez, M.; Lopez-Munguia, A. Production and properties of a dextransucrase from Leuconostoc mesenteroides IBT-PQ isolated from 'Pulque', a traditional Aztec alcoholic beverage. J. Ind. Microbiol. Biotechnol. 1998, 21, 51-56. [CrossRef]

32. Fabre, E.; Bozonnet, S.; Arcache, A.; Willemot, R.-M.; Vignon, M.; Monsan, P.; Remaud-Simeon, M. Role of the Two catalytic domains of DSR-E dextransucrase and their involvement in the formation of highly $\alpha-1,2$ branched dextran. J. Bacteriol. 2005, 187, 296-303. [CrossRef] [PubMed]

33. Kang, H.-K.; Kim, Y.-M.; Kim, D.-M. Functional, genetic, and bioinformatic characterization of dextransucrase (dsrbcb4) gene in Leuconostoc mesenteroides B-1299CB4. J. Microbiol. Biotechnol. 2008, 18, 1050-1058.

34. Kang, H.-K.; Oh, J.-S.; Kim, D. Molecular characterization and expression analysis of the glucansucrase DSRWC from Weissella cibaria synthesizing a $\alpha(1 \rightarrow 6)$ glucan. FEMS Microbiol. Lett. 2009, 292, 33-41. [CrossRef] [PubMed]

35. Kralj, S.; van Geel-Schutten, G.H.; Dondorff, M.M.G.; Kirsanovs, S.; van der Maarel, M.J.E.C.; Dijkhuizen, L.Y. Glucan synthesis in the genus Lactobacillus: Isolation and characterization of glucansucrase genes, enzymes and glucan products from six different strains. Microbiology 2004, 150, 3681-3690. [CrossRef] [PubMed]

36. Leemhuis, H.; Pijning, T.; Dobruchowska, J.M.; van Leeuwen, S.S.; Kralj, S.; Dijkstra, B.W.; Dijkhuizen, L. Glucansucrases: Threedimensional structures, reactions, mechanism, $\alpha$-glucan analysis and their implications in biotechnology and food applications. $J$. Biotechnol. 2013, 163, 250-272. [CrossRef]

37. Monchois, V.; Remaud-Simeon, M.; Monsan, P.; Willemot, R.-M. Cloning and sequencing of a gene coding for an extracellular dextransucrase (DSRB) from Leuconostoc mesenteroides NRRL B-1299 synthesizing only a $\alpha$ (1-6) glucan. FEMS Microbiol. Lett. 1998, 159, 307-315. [CrossRef]

38. Mukasa, H.; Shimamura, A.; Tsumori, H. Purification and characterization of basic glucosyltransferase from Streptococcus mutans serotype C. Biochim. Biophys. Acta BBA Gen. Subj. 1982, 719, 81-89. [CrossRef]

39. Neubauer, H.; Bauche, A.; Mollet, B. Molecular characterization and expression analysis of the dextransucrase DsrD of Leuconostoc mesenteroides Lcc4 in homologous and heterologous Lactococcus lactis cultures. Microbiology 2003, 149, 973-982. [CrossRef]

40. Simpson, C.L.; Cheetham, N.W.; Jacques, N.A. Four glucosyltransferases, GtfJ, GtfK, GtfL and GtfM, from Streptococcus salivarius ATCC 25975. Microbiology 1995, 141, 1451-1460. [CrossRef]

41. Bechtner, J.; Wefers, D.; Schmid, J.; Vogel, R.F.; Jakob, F. Identification and comparison of two closely related dextransucrases released by water kefir borne Lactobacillus hordei TMW 1.1822 and Lactobacillus nagelii TMW 1.1827. Microbiology 2019, 165, 956-966. [CrossRef] [PubMed]

42. Edwards, C.G.; Collins, M.D.; Lawson, P.A.; Rodriguez, A.V. Lactobacillus nagelii sp. nov., an organism isolated from a partially fermented wine. Int. J. Syst. Evol. Microbiol. 2000, 50, 699-702. [CrossRef]

43. Endo, A.; Okada, S. Lactobacillus satsumensis sp. Nov., isolated from mashes of shochu, a traditional japanese distilled spirit made from fermented rice and other starchy materials. Int. J. Syst. Evol. Microbiol. 2005, 55, 83-85. [CrossRef]

44. Kaneuchi, C.; Seki, M.; Komagata, K. Taxonomic study of Lactobacillus mali Carr and Davis 1970 and related strains: Validation of Lactobacillus mali Carr and Davis 1970 over Lactobacillus yamanashiensis Nonomura 1983. Int. J. Syst. Evol. Microbiol. 1988, 38, 269-272. [CrossRef]

45. Zheng, J.; Wittouck, S.; Salvetti, E.; Franz, C.M.; Harris, H.; Mattarelli, P.; O'Toole, P.W.; Pot, B.; Vandamme, P.; Walter, J. A Taxonomic note on the genus Lactobacillus: Description of 23 novel genera, emended description of the genus Lactobacillus Beijerinck 1901, and union of Lactobacillaceae and Leuconostocaceae. Int. J. Syst. Evol. 2020, 2782-2858. [CrossRef]

46. Hilbig, J.; Gisder, J.; Prechtl, R.M.; Herrmann, K.; Weiss, J.; Loeffler, M. Influence of exopolysaccharide-producing lactic acid bacteria on the spreadability of fat-reduced raw fermented sausages (Teewurst). Food Hydrocoll. 2019, 93, 422-431. [CrossRef]

47. Angelin, J.; Kavitha, M. Exopolysaccharides from probiotic bacteria and their health potential. Int. J. Biol. Macromol. 2020, 162, 853-865. [CrossRef] [PubMed]

48. Fukushima, K.; Ikeda, T.; Kuramitsu, H.K. Expression of Streptococcus mutans Gtf Genes in Streptococcus milleri. Infect. Immun. 1992, 60, 2815-2822. [CrossRef] [PubMed]

49. Monchois, V.; Arguello-Morales, M.; Russell, R.R. Isolation of an active catalytic core of Streptococcus downei MFe28 GTF-I glucosyltransferase. J. Bacteriol. 1999, 181, 2290-2292. [CrossRef] [PubMed]

50. Cerning, J. Exocellular polysaccharides produced by lactic acid bacteria. FEMS Microbiol. Lett. 1990, 87, 113-130. [CrossRef] [PubMed]

51. Côté, G.L.; Skory, C.D. Cloning, expression, and characterization of an insoluble glucan-producing glucansucrase from Leuconostoc mesenteroides NRRL B-1118. Appl. Microbiol. Biotechnol. 2012, 93, 2387-2394. [CrossRef] [PubMed]

52. Miao, M.; Bai, A.; Jiang, B.; Song, Y.; Cui, S.W.; Zhang, T. Characterisation of a novel water-soluble polysaccharide from Leuconostoc citreum SK24.002. Food Hydrocoll. 2014, 36, 265-272. [CrossRef]

53. Domingos-Lopes, M.F.P.; Lamosa, P.; Stanton, C.; Ross, R.P.; Silva, C.C.G. Isolation and characterization of an exopolysaccharideproducing Leuconostoc citreum strain from artisanal cheese. Lett. Appl. Microbiol. 2018, 67, 570-578. [CrossRef] [PubMed]

54. Kralj, S.; Stripling, E.; Sanders, P.; van Geel-Schutten, G.H.; Dijkhuizen, L. Highly hydrolytic reuteransucrase from probiotic Lactobacillus reuteri strain ATCC 55730. Appl. Environ. Microbiol. 2005, 71, 3942-3950. [CrossRef] [PubMed]

55. Badel, S.; Bernardi, T.; Michaud, P. New perspectives for lactobacilli exopolysaccharides. Biotechnol. Adv. 2011, 29, 54-66. [CrossRef] 
56. Garai-Ibabe, G.; Dueñas, M.T.; Irastorza, A.; Sierra-Filardi, E.; Werning, M.L.; López, P.; Corbí, A.L.; Fernández de Palencia, P. Naturally occurring 2-substituted (1,3)- $\beta$-D-glucan producing Lactobacillus suebicus and Pediococcus paroulus strains with potential utility in the production of functional foods. Bioresour. Technol. 2010, 101, 9254-9263. [CrossRef] [PubMed]

57. Shi, Q.; Hou, Y.; Xu, Y.; Mørkeberg Krogh, K.B.R.; Tenkanen, M. Enzymatic analysis of levan produced by lactic acid bacteria in fermented doughs. Carbohydr. Polym. 2019, 208, 285-293. [CrossRef]

58. Mensink, M.A.; Frijlink, H.W.; van der Voort Maarschalk, K.; Hinrichs, W.L. Inulin, a flexible oligosaccharide I: Review of its physicochemical characteristics. Carbohydr. Polym. 2015, 130, 405-419. [CrossRef]

59. Ozimek, L.K.; Kralj, S.; Van der Maarel, M.J.; Dijkhuizen, L. The levansucrase and inulosucrase enzymes of Lactobacillus reuteri 121 catalyse processive and non-processive transglycosylation reactions. Microbiology 2006, 152, 1187-1196. [CrossRef]

60. De Vuyst, L.; De Vin, F.; Vaningelgem, F.; Degeest, B. Recent developments in the biosynthesis and applications of heteropolysaccharides from lactic acid bacteria. Int. Dairy J. 2001, 11, 687-707. [CrossRef]

61. Mozzi, F.; Vaningelgem, F.; Hébert, E.M.; Van der Meulen, R.; Foulquié Moreno, M.R.; Font de Valdez, G.; De Vuyst, L. Diversity of heteropolysaccharide-producing lactic acid bacterium strains and their biopolymers. Appl. Environ. Microbiol. 2006, 72, $4431-4435$. [CrossRef]

62. Monsan, P.; Bozonnet, S.; Albenne, C.; Joucla, G.; Willemot, R.-M.; Remaud-Siméon, M. Homopolysaccharides from lactic acid bacteria. Int. Dairy J. 2001, 11, 675-685. [CrossRef]

63. Robyt, J.F. Mechanisms in the glucansucrase synthesis of polysaccharides and oligosaccharides from sucrose. Adv. Carbohydr. Chem. Biochem. 1995, 51, 133-168. [CrossRef]

64. Moradi, Z.; Kalanpour, N. Kefiran, a branched polysaccharide: Preparation, properties and applications: A review. Carbohydr. Polym. 2019, 223, 115100. [CrossRef]

65. Ghasemlou, M.; Khodaiyan, F.; Jahanbin, K.; Gharibzahedi, S.M.T.; Taheri, S. Structural investigation and response surface optimisation for improvement of kefiran production yield from a low-cost culture medium. Food Chem. 2012, 133, 383-389. [CrossRef]

66. West, T.P. Synthesis of the microbial polysaccharide gellan from dairy and plant-based processing coproducts. Polysaccharides 2021, 2, 16. [CrossRef]

67. Kanamarlapudi, S.L.R.K.; Muddada, S. Characterization of exopolysaccharide produced by Streptococcus thermophilus CC30. BioMed Res. Int. 2017, 2017, 4201809. [CrossRef]

68. De Vuyst, L.; Zamfir, M.; Mozzi, F.; Adriany, T.; Marshall, V.; Degeest, B.; Vaningelgem, F. Exopolysaccharide-producing Streptococcus thermophilus strains as functional starter cultures in the production of fermented milks. Int. Dairy J. 2003, 13, 707-717. [CrossRef]

69. Xu, Z.; Guo, Q.; Zhang, H.; Wu, Y.; Hang, X.; Ai, L. Exopolysaccharide produced by Streptococcus thermophiles S-3: Molecular, partial structural and rheological properties. Carbohydr. Polym. 2018, 194, 132-138. [CrossRef] [PubMed]

70. Gentès, M.-C.; St-Gelais, D.; Turgeon, S.L. Gel formation and rheological properties of fermented milk with in situ exopolysaccharide production by lactic acid bacteria. Dairy Sci. Technol. 2011, 91, 645-661. [CrossRef]

71. Gentès, M.-C.; Turgeon, S.L.; St-Gelais, D. Impact of starch and exopolysaccharide-producing lactic acid bacteria on the properties of set and stirred yoghurts. Int. Dairy J. 2016, 55, 79-86. [CrossRef]

72. Zhang, H.; Ren, W.; Guo, Q.; Xiong, Z.; Wang, G.; Xia, Y.; Lai, P.; Yin, B.; Ai, L. Characterization of a yogurt-quality improving exopolysaccharide from Streptococcus thermophilus AR333. Food Hydrocoll. 2018, 81, 220-228. [CrossRef]

73. Bouzar, F.; Cerning, J.; Desmazeaud, M. Exopolysaccharide production and texture-promoting abilities of mixed-strain starter cultures in yogurt production. J. Dairy Sci. 1997, 80, 2310-2317. [CrossRef]

74. Loeffler, M.; Hilbig, J.; Velasco, L.; Weiss, J. Usage of in situ exopolysaccharide-forming lactic acid bacteria in food production: Meat products-A new field of application? Compr. Rev. Food Sci. Food Saf. 2020, 19, 2932-2954. [CrossRef]

75. Xiu, L.; Zhang, H.; Hu, Z.; Liang, Y.; Guo, S.; Yang, M.; Du, R.; Wang, X. Immunostimulatory activity of exopolysaccharides from probiotic Lactobacillus casei WXD030 strain as a novel adjuvant in vitro and in vivo. Food Agric. Immunol. 2018, 29, 1086-1105. [CrossRef]

76. Rani, R.P.; Anandharaj, M.; David Ravindran, A. Characterization of a novel exopolysaccharide produced by Lactobacillus gasseri FR4 and demonstration of its in vitro biological properties. Int. J. Biol. Macromol. 2018, 109, 772-783. [CrossRef]

77. Li, W.; Xia, X.; Tang, W.; Ji, J.; Rui, X.; Chen, X.; Jiang, M.; Zhou, J.; Zhang, Q.; Dong, M. Structural characterization and anticancer activity of cell-bound exopolysaccharide from Lactobacillus helveticus MB2-1. J. Agric. Food Chem. 2015, 63, 3454-3463. [CrossRef]

78. Maeda, H.; Zhu, X.; Suzuki, S.; Suzuki, K.; Kitamura, S. Structural characterization and biological activities of an exopolysaccharide kefiran produced by Lactobacillus kefiranofaciens WT-2BT. J. Agric. Food Chem. 2004, 52, 5533-5538. [CrossRef]

79. Górska, S.; Jachymek, W.; Rybka, J.; Strus, M.; Heczko, P.B.; Gamian, A. Structural and immunochemical studies of neutral exopolysaccharide produced by Lactobacillus johnsonii 142. Carbohydr. Res. 2010, 345, 108-114. [CrossRef]

80. Degeest, B.; Janssens, B.; De Vuyst, L. Exopolysaccharide (EPS) biosynthesis by Lactobacillus sakei 0-1: Production kinetics, enzyme activities and EPS yields. J. Appl. Microbiol. 2001, 91, 470-477. [CrossRef] [PubMed]

81. Wang, J.; Wu, T.; Fang, X.; Min, W.; Yang, Z. Characterization and immunomodulatory activity of an exopolysaccharide produced by Lactobacillus plantarum JLK0142 isolated from fermented dairy tofu. Int. J. Biol. Macromol. 2018, 115, 985-993. [CrossRef] [PubMed] 
82. Liu, Z.; Zhang, Z.; Qiu, L.; Zhang, F.; Xu, X.; Wei, H.; Tao, X. Characterization and bioactivities of the exopolysaccharide from a probiotic strain of Lactobacillus plantarum WLPL04. J. Dairy Sci. 2017, 100, 6895-6905. [CrossRef] [PubMed]

83. Wang, J.; Zhao, X.; Tian, Z.; Yang, Y.; Yang, Z. Characterization of an exopolysaccharide produced by Lactobacillus plantarum YW11 isolated from Tibet kefir. Carbohydr. Polym. 2015, 125, 16-25. [CrossRef] [PubMed]

84. Min, W.-H.; Fang, X.-B.; Wu, T.; Fang, L.; Liu, C.-L.; Wang, J. Characterization and Antioxidant activity of an acidic exopolysaccharide from Lactobacillus plantarum JLAU103. J. Biosci. Bioeng. 2019, 127, 758-766. [CrossRef] [PubMed]

85. Tallon, R.; Bressollier, P.; Urdaci, M.C. Isolation and characterization of two exopolysaccharides produced by Lactobacillus plantarum EP56. Res. Microbiol. 2003, 154, 705-712. [CrossRef]

86. Zhang, L.; Liu, C.; Li, D.; Zhao, Y.; Zhang, X.; Zeng, X.; Yang, Z.; Li, S. Antioxidant activity of an exopolysaccharide isolated from Lactobacillus plantarum C88. Int. J. Biol. Macromol. 2013, 54, 270-275. [CrossRef]

87. Ayyash, M.; Abu-Jdayil, B.; Itsaranuwat, P.; Galiwango, E.; Tamiello-Rosa, C.; Abdullah, H.; Esposito, G.; Hunashal, Y.; Obaid, R.S.; Hamed, F. Characterization, bioactivities, and rheological properties of exopolysaccharide produced by novel probiotic Lactobacillus plantarum C70 isolated from camel milk. Int. J. Biol. Macromol. 2020, 144, 938-946. [CrossRef]

88. Hu, G.; Fu, S.; Liu, H.; Lucia, L.A. Adsorption of cationized Eucalyptus heteropolysaccharides onto chemical and mechanical pulp fibers. Carbohydr. Polym. 2015, 123, 324-330. [CrossRef]

89. Naseri-Nosar, M.; Ziora, Z.M. Wound dressings from naturally-occurring polymers: A review on homopolysaccharide-based composites. Carbohydr. Polym. 2018, 189, 379-398. [CrossRef]

90. Zhou, Y.; Cui, Y.; Qu, X. Exopolysaccharides of lactic acid bacteria: Structure, bioactivity and associations: A review. Carbohydr. Polym. 2019, 207, 317-332. [CrossRef]

91. Schmid, J.; Sieber, V.; Rehm, B. Bacterial exopolysaccharides: Biosynthesis pathways and engineering strategies. Front. Microbiol. 2015, 6, 496. [CrossRef] [PubMed]

92. Korcz, E.; Varga, L. Exopolysaccharides from lactic acid bacteria: Techno-Functional application in the food industry. Trends Food Sci. Technol. 2021, 110, 375-384. [CrossRef]

93. Zeidan, A.A.; Poulsen, V.K.; Janzen, T.; Buldo, P.; Derkx, P.M.; Øregaard, G.; Neves, A.R. Polysaccharide production by lactic acid bacteria: From genes to industrial applications. FEMS Microbiol. Rev. 2017, 41, S168-S200. [CrossRef]

94. Ryan, P.M.; Ross, R.P.; Fitzgerald, G.F.; Caplice, N.M.; Stanton, C. Sugar-Coated: Exopolysaccharide producing lactic acid bacteria for food and human health applications. Food Funct. 2015, 6, 679-693. [CrossRef]

95. De Vuyst, L.; Degeest, B. Heteropolysaccharides from lactic acid bacteria. FEMS Microbiol. Rev. 1999, 23, 153-177. [CrossRef]

96. Kumar, R.; Bansal, P.; Singh, J.; Dhanda, S. Purification, partial structural characterization and health benefits of exopolysaccharides from potential probiotic Pediococcus acidilactici NCDC 252. Process. Biochem. 2020, 99, 79-86. [CrossRef]

97. Cantarel, B.L.; Coutinho, P.M.; Rancurel, C.; Bernard, T.; Lombard, V.; Henrissat, B. The carbohydrate-active enzymes database (CAZy): An expert resource for glycogenomics. Nucleic Acids Res. 2009, 37, D233-D238. [CrossRef] [PubMed]

98. De Vuyst, L.; Monnet, V.; Chapot-Chartier, M.-P. Cell walls and exopolysaccharides of lactic acid bacteria. In Proceedings of the The 10th LAB Symposium - Thirty Years of Research on Lactic Acid Bacteria; Media Labs: Rotterdam, The Netherlands, 2011 ; pp. 37-59.

99. Korakli, M.; Vogel, R.F. Structure/function relationship of homopolysaccharide producing glycansucrases and therapeutic potential of their synthesised glycans. Appl. Microbiol. Biotechnol. 2006, 71, 790-803. [CrossRef] [PubMed]

100. Leemhuis, H.; Pijning, T.; Dobruchowska, J.M.; Dijkstra, B.W.; Dijkhuizen, L. Glycosidic bond specificity of glucansucrases: On the role of acceptor substrate binding residues. Biocatal. Biotransform. 2012, 30, 366-376. [CrossRef]

101. Laws, A.; Gu, Y.; Marshall, V. Biosynthesis, characterisation, and design of bacterial exopolysaccharides from lactic acid bacteria Biotechnol. Adv. 2001, 19, 597-625. [CrossRef]

102. Pessione, E. Lactic acid bacteria contribution to gut microbiota complexity: Lights and shadows. Front. Cell. Infect. Microbiol. 2012, 2, 86. [CrossRef]

103. Duboc, P.; Mollet, B. Applications of exopolysaccharides in the dairy industry. Int. Dairy J. 2001, 11, 759-768. [CrossRef]

104. Monchois, V.; Willemot, R.-M.; Monsan, P. Glucansucrases: Mechanism of action and structure-function relationships. FEMS Microbiol. Rev. 1999, 23, 131-151. [CrossRef]

105. Ruas-Madiedo, P.; de los Reyes-Gavilán, C.G. Invited review: Methods for the screening, isolation, and characterization of exopolysaccharides produced by lactic acid bacteria. J. Dairy Sci. 2005, 88, 843-856. [CrossRef]

106. Bergmaier, D.; Champagne, C.P.; Lacroix, C. Growth and exopolysaccharide production during free and immobilized cell chemostat culture of Lactobacillus rhamnosus RW-9595M. J. Appl. Microbiol. 2005, 98, 272-284. [CrossRef]

107. Ruas-Madiedo, P.; Salazar, N.; De los Reyes-Gavilan, C.G. Biosynthesis and chemical composition of exopolysaccharides produced by lactic acid bacteria. Bact. Polysacch. Curr. Innov. Future Trends 2009, 279-310.

108. Cirrincione, S.; Breuer, Y.; Mangiapane, E.; Mazzoli, R.; Pessione, E. "Ropy" phenotype, exopolysaccharides and metabolism: Study on food isolated potential probiotics LAB. Microbiol. Res. 2018, 214, 137-145. [CrossRef]

109. Fukuda, K.; Shi, T.; Nagami, K.; Leo, F.; Nakamura, T.; Yasuda, K.; Senda, A.; Motoshima, H.; Urashima, T. Effects of carbohydrate source on physicochemical properties of the exopolysaccharide produced by Lactobacillus fermentum TDS030603 in a chemically defined medium. Carbohydr. Polym. 2010, 79, 1040-1045. [CrossRef]

110. Barcelos, M.C.S.; Vespermann, K.A.C.; Pelissari, F.M.; Molina, G. Current status of biotechnological production and applications of microbial exopolysaccharides. Crit. Rev. Food Sci. Nutr. 2020, 60, 1475-1495. [CrossRef] 
111. Madhuri, K.V.; Prabhakar, K.V. Microbial exopolysaccharides: Biosynthesis and potential applications. Orient. J. Chem. 2014, 30, 1401. [CrossRef]

112. Prete, R.; Alam, M.K.; Perpetuini, G.; Perla, C.; Pittia, P.; Corsetti, A. Lactic acid bacteria exopolysaccharides producers: A sustainable tool for functional foods. Foods 2021, 10, 1653. [CrossRef]

113. Mozzi, F.; Rollán, G.; De Giori, G.S.; De Valdez, G.F. Effect of galactose and glucose on the exopolysaccharide production and the activities of biosynthetic enzymes in Lactobacillus casei CRL 87. J. Appl. Microbiol. 2001, 91, 160-167. [CrossRef]

114. Petry, S.; Furlan, S.; Crepeau, M.-J.; Cerning, J.; Desmazeaud, M. Factors affecting exocellular polysaccharide production by Lactobacillus delbrueckii subsp. bulgaricus grown in a chemically defined medium. Appl. Environ. Microbiol. 2000, 66, 3427-3431. [CrossRef]

115. Robitaille, G.; Moineau, S.; St-Gelais, D.; Vadeboncoeur, C.; Britten, M. Detection and quantification of capsular exopolysaccharides from Streptococcus thermophilus using lectin probes. J. Dairy Sci. 2006, 89, 4156-4162. [CrossRef]

116. Zisu, B.; Shah, N.P. Effects of $\mathrm{pH}$, temperature, supplementation with whey protein concentrate, and adjunct cultures on the production of exopolysaccharides by Streptococcus thermophilus 1275. J. Dairy Sci. 2003, 86, 3405-3415. [CrossRef]

117. Vuyst, D.; de Ven, V. Production by and isolation of exopolysaccharides from Streptococcus thermophilus grown in a milk medium and evidence for their growth-associated biosynthesis. J. Appl. Microbiol. 1998, 84, 1059-1068. [CrossRef]

118. Dubois, M.; Gilles, K.A.; Hamilton, J.K.; Rebers, P.A.; Smith, F. Colorimetric method for determination of sugars and related substances. Anal. Chem. 1956, 28, 350-356. [CrossRef]

119. Albalasmeh, A.A.; Berhe, A.A.; Ghezzehei, T.A. A new method for rapid determination of carbohydrate and total carbon concentrations using uv spectrophotometry. Carbohydr. Polym. 2013, 97, 253-261. [CrossRef]

120. Wu, J.; Zhang, Y.; Ye, L.; Wang, C. The anti-cancer effects and mechanisms of lactic acid bacteria exopolysaccharides in vitro: A review. Carbohydr. Polym. 2021, 253, 117308. [CrossRef]

121. Rana, S.; Upadhyay, L.S.B. Microbial exopolysaccharides: Synthesis pathways, types and their commercial applications. Int. J. Biol. Macromol. 2020, 157, 577-583. [CrossRef]

122. Zhang, G.; Zhang, W.; Sun, L.; Sadiq, F.A.; Yang, Y.; Gao, J.; Sang, Y. Preparation screening, production optimization and characterization of exopolysaccharides produced by Lactobacillus sanfranciscensis Ls-1001 isolated from chinese traditional sourdough. Int. J. Biol. Macromol. 2019, 139, 1295-1303. [CrossRef]

123. Berthold-Pluta, A.M.; Pluta, A.S.; Garbowska, M.; Stasiak-Różańska, L. Exopolysaccharide-producing lactic acid bacteria-Healthpromoting properties and application in the dairy industry. Adv. Microbiol. 2019, 58, 191-204. [CrossRef]

124. Zarour, K.; Vieco, N.; Pérez-Ramos, A.; Nácher-Vázquez, M.; Mohedano, M.L.; López, P. Chapter 4-Food ingredients synthesized by lactic acid bacteria. In Microbial Production of Food Ingredients and Additives; Handbook of Food Bioengineering; Holban, A.M., Grumezescu, A.M., Eds.; Academic Press: Cambridge, MA, USA, 2017; pp. 89-124. ISBN 978-0-12-811520-6.

125. Tiwari, S.; Kavitake, D.; Devi, P.B.; Halady, P.S. Bacterial exopolysaccharides for improvement of technological, functional and rheological properties of yoghurt. Int. J. Biol. Macromol. 2021, 183, 1585-1595. [CrossRef]

126. Han, X.; Yang, Z.; Jing, X.; Yu, P.; Zhang, Y.; Yi, H.; Zhang, L. Improvement of the texture of yogurt by use of exopolysaccharide producing lactic acid bacteria. BioMed Res. Int. 2016, 2016, e7945675. [CrossRef]

127. Patel, A.; Prajapati, J. Food and Health Applications of exopolysaccharides produced by lactic acid bacteria. Adv. Dairy Res. 2013, 1, 1-7. [CrossRef]

128. London, L.E.E.; Chaurin, V.; Auty, M.A.E.; Fenelon, M.A.; Fitzgerald, G.F.; Ross, R.P.; Stanton, C. Use of Lactobacillus mucosae DPC 6426, an exopolysaccharide-producing strain, positively influences the techno-functional properties of yoghurt. Int. Dairy J. 2015, 40, 33-38. [CrossRef]

129. Settanni, L.; Moschetti, G. Non-Starter lactic acid bacteria used to improve cheese quality and provide health benefits. Food Microbiol. 2010, 27, 691-697. [CrossRef]

130. Broadbent, J.R.; McMahon, D.J.; Oberg, C.J.; Welker, D.L. Use of exopolysaccharide-producing cultures to improve the functionality of low fat cheese. Int. Dairy J. 2001, 11, 433-439. [CrossRef]

131. Costa, N.E.; Hannon, J.A.; Guinee, T.P.; Auty, M.A.E.; McSweeney, P.L.H.; Beresford, T.P. Effect of exopolysaccharide produced by isogenic strains of Lactococcus lactis on half-fat Cheddar cheese. J. Dairy Sci. 2010, 93, 3469-3486. [CrossRef] [PubMed]

132. Wang, B.; Song, Q.; Zhao, F.; Xiao, H.; Zhou, Z.; Han, Y. Purification and characterization of dextran produced by Leuconostoc pseudomesenteroides PC as a potential exopolysaccharide suitable for food applications. Process. Biochem. 2019, 87, 187-195. [CrossRef]

133. Şanli, T.; Gursel, A.; Şanli, E.; Acar, E.; Benli, M. The effect of using an exopolysaccharide-producing culture on the physicochemical properties of low-fat and reduced-fat Kasar cheeses. Int. J. Dairy Technol. 2013, 66, 535-542. [CrossRef]

134. Surber, G.; Schäper, C.; Wefers, D.; Rohm, H.; Jaros, D. Exopolysaccharides from Lactococcus lactis affect manufacture, texture and sensory properties of concentrated acid milk gel suspensions (fresh cheese). Int. Dairy J. 2021, 112, 104854. [CrossRef]

135. Coelho Nepomuceno, R.S.C.; Gonçalves Costa, L.C., Jr.; Bueno Costa, R.G. Exopolysaccharide-producing culture in the manufacture of prato cheese. LWT Food Sci. Technol. 2016, 72, 383-389. [CrossRef]

136. Rehman, R.; Wang, Y.; Wang, J.; Geng, W. Physicochemical analysis of Mozzarella cheese produced and developed by the novel EPS-producing strain Lactobacillus kefiranofaciens ZW3. Int. J. Dairy Technol. 2018, 71, 90-98. [CrossRef] 
137. Carrero-Puentes, S.; Fuenmayor, C.; Jiménez-Pérez, C.; Guzmán-Rodríguez, F.; Gómez-Ruiz, L.; Rodríguez-Serrano, G.; Alatorre-Santamaría, S.; García-Garibay, M.; Cruz-Guerrero, A. Development and characterization of an exopolysaccharidefunctionalized acid whey cheese (Requesón) using Lactobacillus delbrueckii ssp. bulgaricus. J. Food Process. Preserv. 2021 , e16095. [CrossRef]

138. Hamet, M.F.; Piermaria, J.A.; Abraham, A.G. Selection of EPS-producing Lactobacillus strains isolated from kefir grains and rheological characterization of the fermented milks. LWT Food Sci. Technol. 2015, 63, 129-135. [CrossRef]

139. Wang, H.; Sun, X.; Song, X.; Guo, M. Effects of kefir grains from different origins on proteolysis and volatile profile of goat milk kefir. Food Chem. 2021, 339, 128099. [CrossRef] [PubMed]

140. Wang, Y.; Li, C.; Liu, P.; Ahmed, Z.; Xiao, P.; Bai, X. Physical characterization of exopolysaccharide produced by Lactobacillus plantarum KF5 isolated from Tibet kefir. Carbohydr. Polym. 2010, 82, 895-903. [CrossRef]

141. You, X.; Yang, L.; Zhao, X.; Ma, K.; Chen, X.; Zhang, C.; Wang, G.; Dong, M.; Rui, X.; Zhang, Q. Isolation, purification, characterization and immunostimulatory activity of an exopolysaccharide produced by Lactobacillus pentosus LZ-R-17 isolated from Tibetan kefir. Int. J. Biol. Macromol. 2020, 158, 408-419. [CrossRef]

142. Botelho, P.S.; Maciel, M.I.S.; Bueno, L.A.; Marques, M.d.F.F.; Marques, D.N.; Sarmento Silva, T.M. Characterisation of a new exopolysaccharide obtained from of fermented kefir grains in soymilk. Carbohydr. Polym. 2014, 107, 1-6. [CrossRef]

143. Egea, M.B.; dos Santos, D.C.; de Oliveira Filho, J.G.; da Costa Ores, J.; Takeuchi, K.P.; Lemes, A.C. A review of nondairy kefir products: Their characteristics and potential human health benefits. Crit. Rev. Food Sci. Nutr. 2020, 60, 1-17. [CrossRef]

144. Hickisch, A.; Beer, R.; Vogel, R.F.; Toelstede, S. Influence of lupin-based milk alternative heat treatment and exopolysaccharideproducing lactic acid bacteria on the physical characteristics of lupin-based yogurt alternatives. Food Res. Int. 2016, 84, 180-188. [CrossRef]

145. Peyer, L.C.; Zannini, E.; Arendt, E.K. Lactic acid bacteria as sensory biomodulators for fermented cereal-based beverages. Trends Food Sci. Technol. 2016, 54, 17-25. [CrossRef]

146. Lorusso, A.; Coda, R.; Montemurro, M.; Rizzello, C.G. Use of selected lactic acid bacteria and quinoa flour for manufacturing novel yogurt-like beverages. Foods 2018, 7, 51. [CrossRef]

147. Zannini, E.; Jeske, S.; Lynch, K.M.; Arendt, E.K. Development of novel quinoa-based yoghurt fermented with dextran producer Weissella cibaria MG1. Int. J. Food Microbiol. 2018, 268, 19-26. [CrossRef] [PubMed]

148. Păcularu-Burada, B.; Georgescu, L.A.; Bahrim, G.-E. Current approaches in sourdough production with valuable characteristics for technological and functional applications. Ann. Univ. Dunarea Jos Galati Fascicle VI Food Technol. 2020, 44, 132-148. [CrossRef]

149. Sahin, A.W.; Zannini, E.; Coffey, A.; Arendt, E.K. Sugar reduction in bakery products: Current strategies and sourdough technology as a potential novel approach. Food Res. Int. 2019, 126, 108583. [CrossRef]

150. Tinzl-Malang, S.K.; Grattepanche, F.; Rast, P.; Fischer, P.; Sych, J.; Lacroix, C. Purified exopolysaccharides from Weissella confusa 11GU-1 and Propionibacterium freudenreichii JS15 act synergistically on bread structure to prevent staling. LWT 2020, 127, 109375 [CrossRef]

151. Tang, X.; Liu, R.; Huang, W.; Zhang, B.; Wu, Y.; Zhuang, J.; Omedi, J.O.; Wang, F.; Zheng, J. Impact of in situ formed exopolysaccharides on dough performance and quality of Chinese steamed bread. LWT 2018, 96, 519-525. [CrossRef]

152. Valerio, F.; Bavaro, A.R.; Di Biase, M.; Lonigro, S.L.; Logrieco, A.F.; Lavermicocca, P. Effect of amaranth and quinoa flours on exopolysaccharide production and protein profile of liquid sourdough fermented by Weissella cibaria and Lactobacillus plantarum. Front. Microbiol. 2020, 11, 967. [CrossRef]

153. Zhang, B.; Omedi, J.O.; Zheng, J.; Huang, W.; Jia, C.; Zhou, L.; Zou, Q.; Li, N.; Gao, T. Exopolysaccharides in sourdough fermented by Weissella confusa QS813 protected protein matrix and quality of frozen gluten-red bean dough during freeze-thaw cycles. Food Biosci. 2021, 43, 101180. [CrossRef]

154. Akobeng, A.K.; Singh, P.; Kumar, M.; Al Khodor, S. Role of the gut microbiota in the pathogenesis of coeliac disease and potential therapeutic implications. Eur. J. Nutr. 2020, 59, 3369-3390. [CrossRef]

155. Xu, D.; Hu, Y.; Wu, F.; Jin, Y.; Xu, X.; Gänzle, M.G. Comparison of the functionality of exopolysaccharides produced by sourdough lactic acid bacteria in bread and steamed bread. J. Agric. Food Chem. 2020, 68, 8907-8914. [CrossRef]

156. Kumar, Y. Development of low-fat/reduced-fat processed meat products using fat replacers and analogues. Food Rev. Int. 2021, 37, 296-312. [CrossRef]

157. Andrès, S.; Zaritzky, N.; Califano, A. The effect of whey protein concentrates and hydrocolloids on the texture and colour characteristics of chicken sausages. Int. J. Food Sci. Technol. 2006, 41, 954-961. [CrossRef]

158. Asioli, D.; Aschemann-Witzel, J.; Caputo, V.; Vecchio, R.; Annunziata, A.; Næs, T.; Varela, P. Making sense of the "clean label" trends: A review of consumer food choice behavior and discussion of industry implications. Food Res. Int. 2017, 99, 58-71. [CrossRef] [PubMed]

159. Gibis, M.; Schuh, V.; Weiss, J. Effects of carboxymethyl cellulose (CMC) and microcrystalline cellulose (MCC) as fat replacers on the microstructure and sensory characteristics of fried beef patties. Food Hydrocoll. 2015, 45, 236-246. [CrossRef]

160. Verbeken, D.; Neirinck, N.; Van Der Meeren, P.; Dewettinck, K. Influence of K-Carrageenan on the thermal gelation of salt-soluble meat proteins. Meat Sci. 2005, 70, 161-166. [CrossRef]

161. Hilbig, J.; Loeffler, M.; Herrmann, K.; Weiss, J. The influence of exopolysaccharide-producing lactic acid bacteria on reconstructed ham. Int. J. Food Sci. Technol. 2019, 54, 2763-2769. [CrossRef] 
162. Dertli, E.; Yilmaz, M.T.; Tatlisu, N.B.; Toker, O.S.; Cankurt, H.; Sagdic, O. Effects of in situ exopolysaccharide production and fermentation conditions on physicochemical, microbiological, textural and microstructural properties of Turkish-type fermented sausage (Sucuk). Meat Sci. 2016, 121, 156-165. [CrossRef]

163. Abid, Y.; Casillo, A.; Gharsallah, H.; Joulak, I.; Lanzetta, R.; Corsaro, M.M.; Attia, H.; Azabou, S. Production and structural characterization of exopolysaccharides from newly isolated probiotic lactic acid bacteria. Int. J. Biol. Macromol. 2018, 108, 719-728. [CrossRef]

164. Harutoshi, T. Exopolysaccharides of lactic acid bacteria for food and colon health applications. In Lactic Acid Bacteria-R E D for Food, Health and Livestock Purposes; IntechOpen: London, UK, 2013.

165. Korcz, E.; Kerényi, Z.; Varga, L. Dietary fibers, prebiotics, and exopolysaccharides produced by lactic acid bacteria: Potential health benefits with special regard to cholesterol-lowering effects. Food Funct. 2018, 9, 3057-3068. [CrossRef]

166. Nwodo, U.U.; Green, E.; Okoh, A.I. Bacterial exopolysaccharides: Functionality and prospects. Int. J. Mol. Sci. 2012, 13, 14002-14015. [CrossRef] [PubMed]

167. Ruas-Madiedo, P.; Hugenholtz, J.; Zoon, P. An Overview of the functionality of exopolysaccharides produced by lactic acid bacteria. Int. Dairy J. 2002, 12, 163-171. [CrossRef]

168. Saadat, Y.R.; Khosroushahi, A.Y.; Gargari, B.P. A comprehensive review of anticancer, immunomodulatory and health beneficial effects of the lactic acid bacteria exopolysaccharides. Carbohydr. Polym. 2019, 217, 79-89. [CrossRef]

169. Singh, P.; Saini, P. Food and health potentials of exopolysaccharides derived from Lactobacilli. Microbiol. Res. J. Int. 2017, $22,1-14$. [CrossRef]

170. Looijesteijn, P.J.; Trapet, L.; de Vries, E.; Abee, T.; Hugenholtz, J. Physiological function of exopolysaccharides produced by Lactococcus lactis. Int. J. Food Microbiol. 2001, 64, 71-80. [CrossRef]

171. Sharma, S.; Padhi, S.; Kumari, M.; Rai, A.K.; Sahoo, D. Bioactive Compounds in Fermented Foods. Health Aspects; CRC Press: Boca Raton, FL, USA, 2021; p. 48.

172. Balzaretti, S.; Taverniti, V.; Guglielmetti, S.; Fiore, W.; Minuzzo, M.; Ngo, H.N.; Ngere, J.B.; Sadiq, S.; Humphreys, P.N.; Laws, A.P. A novel rhamnose-rich hetero-exopolysaccharide isolated from Lactobacillus paracasei DG activates THP-1 human monocytic cells. Appl. Environ. Microbiol. 2017, 83, e02702-e02716. [CrossRef]

173. Bengoa, A.A.; Llamas, M.G.; Iraporda, C.; Dueñas, M.T.; Abraham, A.G.; Garrote, G.L. Impact of growth temperature on exopolysaccharide production and probiotic properties of Lactobacillus paracasei strains isolated from kefir grains. Food Microbiol. 2018, 69, 212-218. [CrossRef]

174. Hooshdar, P.; Kermanshahi, R.K.; Ghadam, P.; Khosravi-Darani, K. A review on production of exopolysaccharide and biofilm in probiotics like Lactobacilli and methods of analysis. Biointerface Res. Appl. Chem. 2020, 10, 6058-6075.

175. Oerlemans, M.M.P.; Akkerman, R.; Ferrari, M.; Walvoort, M.T.C.; de Vos, P. Benefits of bacteria-derived exopolysaccharides on gastrointestinal microbiota, immunity and health. J. Funct. Foods 2021, 76, 104289. [CrossRef]

176. Abdalla, A.K.; Ayyash, M.M.; Olaimat, A.N.; Osaili, T.M.; Al-Nabulsi, A.A.; Shah, N.P.; Holley, R. Exopolysaccharides as antimicrobial agents: Mechanism and spectrum of activity. Front. Microbiol. 2021, 12, 664395. [CrossRef]

177. Patten, D.A.; Laws, A.P. Lactobacillus-produced exopolysaccharides and their potential health benefits: A review. Benef. Microbes 2015, 6, 457-471. [CrossRef] [PubMed]

178. Abid, Y.; Azabou, S.; Blecker, C.; Gharsallaoui, A.; Corsaro, M.M.; Besbes, S.; Attia, H. Rheological and emulsifying properties of an exopolysaccharide produced by potential probiotic Leuconostoc citreum-BMS strain. Carbohydr. Polym. 2021, 256, 117523. [CrossRef] [PubMed]

179. Bomfim, V.B.; Neto, J.H.P.L.; Leite, K.S.; de Andrade Vieira, É.; Iacomini, M.; Silva, C.M.; dos Santos, K.M.O.; Cardarelli, H.R Partial characterization and antioxidant activity of exopolysaccharides produced by Lactobacillus plantarum CNPC003. LWT 2020, 127, 109349. [CrossRef]

180. Du, R.; Qiao, X.; Zhao, F.; Song, Q.; Zhou, Q.; Wang, Y.; Pan, L.; Han, Y.; Zhou, Z. Purification, characterization and antioxidant activity of dextran produced by Leuconostoc pseudomesenteroides from homemade wine. Carbohydr. Polym. 2018, 198, 529-536. [CrossRef] [PubMed]

181. Freitas, F.; Alves, V.D.; Reis, M.A. Advances in bacterial exopolysaccharides: From production to biotechnological applications. Trends Biotechnol. 2011, 29, 388-398. [CrossRef] [PubMed]

182. Nehal, F.; Sahnoun, M.; Smaoui, S.; Jaouadi, B.; Bejar, S.; Mohammed, S. Characterization, High production and antimicrobial activity of exopolysaccharides from Lactococcus lactis F-Mou. Microb. Pathog. 2019, 132, 10-19. [CrossRef]

183. Ripari, V. Techno-functional role of exopolysaccharides in cereal-based, yogurt-like beverages. Beverages 2019, 5, 16. [CrossRef]

184. Moscovici, M. Present and future medical applications of microbial exopolysaccharides. Front. Microbiol. 2015, 6, 1012. [CrossRef]

185. Ruas-Madiedo, P. Biosynthesis and bioactivity of exopolysaccharides produced by probiotic bacteria. Food Oligosacch. Prod. Anal. Bioact. 2014, 118-133.

186. Darilmaz, D.O.; Beyatli, Y. Investigating hydrophobicity and the effect of exopolysaccharide on aggregation properties of dairy propionibacteria isolated from Turkish homemade cheeses. J. Food Prot. 2012, 75, 359-365. [CrossRef]

187. Abedfar, A.; Hossininezhad, M. Overview of the most important characterization of exopolysaccharides produced by probiotics bacteria and their biological function. J. Environ. Sci. Toxicol. Food Technol. 2016, 10, 47-55. 
188. Hamdy, A.A.; Elattal, N.A.; Amin, M.A.; Ali, A.E.; Mansour, N.M.; Awad, G.E.; Farrag, A.R.H.; Esawy, M.A. In Vivo Assessment of possible probiotic properties of Bacillus subtilis and prebiotic properties of levan. Biocatal. Agric. Biotechnol. 2018, 13, 190-197. [CrossRef]

189. Pan, L.; Han, Y.; Zhou, Z. In vitro prebiotic activities of exopolysaccharide from Leuconostoc pseudomesenteroides XG5 and its effect on the gut microbiota of mice. J. Funct. Foods 2020, 67, 103853. [CrossRef]

190. Hidalgo-Cantabrana, C.; López, P.; Gueimonde, M.; Clara, G.; Suárez, A.; Margolles, A.; Ruas-Madiedo, P. Immune modulation capability of exopolysaccharides synthesised by lactic acid bacteria and bifidobacteria. Probiotics Antimicrob. Proteins 2012, 4, 227-237. [CrossRef]

191. Jin, M.; Wang, Y.; Xu, C.; Lu, Z.; Huang, M.; Wang, Y. Preparation and biological activities of an exopolysaccharide produced by Enterobacter cloacae Z0206. Carbohydr. Polym. 2010, 81, 607-611. [CrossRef]

192. Tzianabos, A.O. Polysaccharide immunomodulators as therapeutic agents: Structural aspects and biologic function. Clin. Microbiol. Rev. 2000, 13, 523-533. [CrossRef]

193. Makino, S.; Ikegami, S.; Kano, H.; Sashihara, T.; Sugano, H.; Horiuchi, H.; Saito, T.; Oda, M. Immunomodulatory effects of polysaccharides produced by Lactobacillus delbrueckii ssp. bulgaricus OLL1073R-1. J. Dairy Sci. 2006, 89, 2873-2881. [CrossRef]

194. Hidalgo-Cantabrana, C.; Nikolic, M.; López, P.; Suárez, A.; Miljkovic, M.; Kojic, M.; Margolles, A.; Golic, N.; Ruas-Madiedo, P. Exopolysaccharide-producing Bifidobacterium animalis subsp. lactis strains and their polymers elicit different responses on immune cells from blood and gut associated lymphoid tissue. Anaerobe 2014, 26, 24-30. [CrossRef]

195. Surayot, U.; Wang, J.; Seesuriyachan, P.; Kuntiya, A.; Tabarsa, M.; Lee, Y.; Kim, J.-K.; Park, W.; You, S. Exopolysaccharides from lactic acid bacteria: Structural analysis, molecular weight effect on immunomodulation. Int. J. Biol. Macromol. 2014, 68, 233-240. [CrossRef] [PubMed]

196. Ismail, B.; Nampoothiri, K.M. Exposition of antitumour activity of a chemically characterized exopolysaccharide from a probiotic Lactobacillus plantarum MTCC 9510. Biologia 2013, 68, 1041-1047. [CrossRef]

197. Kitazawa, H.; Harata, T.; Uemura, J.; Saito, T.; Kaneko, T.; Itoh, T. Phosphate group requirement for mitogenic activation of lymphocytes by an extracellular phosphopolysaccharide from Lactobacillus delbrueckii ssp. bulgaricus. Int. J. Food Microbiol. 1998, 40, 169-175. [CrossRef]

198. Vitlic, A.; Sadiq, S.; Ahmed, H.I.; Ale, E.C.; Binetti, A.G.; Collett, A.; Humpreys, P.N.; Laws, A.P. Evidence for the modulation of the immune response in peripheral blood mononuclear cells after stimulation with a high molecular weight $\beta$-glucan isolated from Lactobacillus fermentum Lf2. bioRxiv 2018, 400267. [CrossRef]

199. Chaisuwan, W.; Jantanasakulwong, K.; Wangtueai, S.; Phimolsiripol, Y.; Chaiyaso, T.; Techapun, C.; Phongthai, S.; You, S.; Regenstein, J.M.; Seesuriyachan, P. Microbial exopolysaccharides for immune enhancement: Fermentation, modifications and bioactivities. Food Biosci. 2020, 35, 100564. [CrossRef]

200. Chen, Y.-C.; Wu, Y.-J.; Hu, C.-Y. Monosaccharide composition influence and immunomodulatory effects of probiotic exopolysaccharides. Int. J. Biol. Macromol. 2019, 133, 575-582. [CrossRef]

201. Jones, S.E.; Paynich, M.L.; Knight, K.L. Exopolysaccharides: Sweet success with probiotic therapeutics. Inflamm. Cell Signal. 2014, 1, e334. [CrossRef]

202. Liu, C.-T.; Chu, F.-J.; Chou, C.-C.; Yu, R.-C. Antiproliferative and anticytotoxic effects of cell fractions and exopolysaccharides from Lactobacillus casei 01. Mutat. Res. Toxicol. Environ. Mutagen. 2011, 721, 157-162. [CrossRef]

203. Dilna, S.V.; Surya, H.; Aswathy, R.G.; Varsha, K.K.; Sakthikumar, D.N.; Pandey, A.; Nampoothiri, K.M. Characterization of an exopolysaccharide with potential health-benefit properties from a probiotic Lactobacillus plantarum RJF4. LWT Food Sci. Technol. 2015, 64, 1179-1186. [CrossRef]

204. Domingos-Lopes, M.F.P.; Nagy, A.; Stanton, C.; Ross, P.R.; Gelencsér, E.; Silva, C.C.G. Immunomodulatory activity of exopolysaccharide producing Leuconostoc citreum strain isolated from Pico cheese. J. Funct. Foods 2017, 33, 235-243. [CrossRef]

205. Schiavi, E.; Plattner, S.; Rodriguez-Perez, N.; Barcik, W.; Frei, R.; Ferstl, R.; Kurnik-Lucka, M.; Groeger, D.; Grant, R.; Roper, J.; et al Exopolysaccharide from Bifidobacterium longum subsp. longum $35624^{\mathrm{TM}}$ modulates murine allergic airway responses. Benef. Microbes 2018, 9, 761-773. [CrossRef]

206. Nowak, B.; Śróttek, M.; Ciszek-Lenda, M.; Skałkowska, A.; Gamian, A.; Górska, S.; Marcinkiewicz, J. Exopolysaccharide from Lactobacillus rhamnosus KL37 inhibits T cell-dependent immune response in mice. Arch. Immunol. Ther. Exp. 2020, 68, 17. [CrossRef]

207. Matsuzaki, C.; Hayakawa, A.; Matsumoto, K.; Katoh, T.; Yamamoto, K.; Hisa, K. Exopolysaccharides produced by Leuconostoc mesenteroides strain NTM048 as an immunostimulant to enhance the mucosal barrier and influence the systemic immune response. J. Agric. Food Chem. 2015, 63, 7009-7015. [CrossRef]

208. Liu, L.; Wu, J.; Zhang, J.; Li, Z.; Wang, C.; Chen, M.; Wang, Y.; Sun, Y.; Wang, L.; Luo, C. A Compatibility assay of ursolic acid and foodborne microbial exopolysaccharides by antioxidant power and anti-proliferative properties in hepatocarcinoma cells. J. Food Agric. Environ. 2012, 10, 111-114.

209. Nguyen, N.D.; Le, A.Q.; Nguyen, Q.H. Electron beam $/ \gamma$-ray irradiation synthesis of gold nanoparticles and investigation of antioxidant activity. Adv. Nat. Sci. Nanosci. Nanotechnol. 2014, 5, 045002. [CrossRef]

210. Adesulu-Dahunsi, A.T.; Sanni, A.I.; Jeyaram, K. Production, characterization and in vitro antioxidant activities of exopolysaccharide from Weissella cibaria GA44. LWT 2018, 87, 432-442. [CrossRef] 
211. Liu, Z.; Dong, L.; Jia, K.; Zhan, H.; Zhang, Z.; Shah, N.P.; Tao, X.; Wei, H. Sulfonation of Lactobacillus plantarum WLPL04 exopolysaccharide amplifies its antioxidant activities in vitro and in a Caco-2 cell model. J. Dairy Sci. 2019, 102, 5922-5932. [CrossRef] [PubMed]

212. Soh, H.-S.; Kim, C.-S.; Lee, S.-P. A new in vitro assay of cholesterol adsorption by food and microbial polysaccharides. J. Med. Food 2003, 6, 225-230. [CrossRef] [PubMed]

213. Nakajima, H.; Suzuki, Y.; Hirota, T. Cholesterol lowering activity of ropy fermented milk. J. Food Sci. 1992, 57, 1327-1329. [CrossRef]

214. Ai, L.; Zhang, H.; Guo, B.; Chen, W.; Wu, Z.; Wu, Y. Preparation, partial characterization and bioactivity of exopolysaccharides from Lactobacillus casei LC2W. Carbohydr. Polym. 2008, 74, 353-357. [CrossRef]

215. Merghni, A.; Dallel, I.; Noumi, E.; Kadmi, Y.; Hentati, H.; Tobji, S.; Amor, A.B.; Mastouri, M. Antioxidant and antiproliferative potential of biosurfactants isolated from Lactobacillus casei and their anti-biofilm effect in oral Staphylococcus aureus strains. Microb. Pathog. 2017, 104, 84-89. [CrossRef]

216. Wang, K.; Li, W.; Rui, X.; Chen, X.; Jiang, M.; Dong, M. Characterization of a novel exopolysaccharide with antitumor activity from Lactobacillus plantarum 70810. Int. J. Biol. Macromol. 2014, 63, 133-139. [CrossRef]

217. Bhat, B.; Bajaj, B.K. Hypocholesterolemic and bioactive potential of exopolysaccharide from a probiotic Enterococcus faecium K1 isolated from Kalarei. Bioresour. Technol. 2018, 254, 264-267. [CrossRef]

218. Rahnama Vosough, P.; Habibi Najafi, M.B.; Edalatian Dovom, M.R.; Javadmanesh, A.; Mayo, B. Evaluation of antioxidant, antibacterial and cytotoxicity activities of exopolysaccharide from Enterococcus strains isolated from traditional Iranian kishk. J. Food Meas. Charact. 2021, 15, 5221-5230. [CrossRef]

219. Trabelsi, I.; Ktari, N.; Ben Slima, S.; Triki, M.; Bardaa, S.; Mnif, H.; Ben Salah, R. Evaluation of dermal wound healing activity and in vitro antibacterial and antioxidant activities of a new exopolysaccharide produced by Lactobacillus Sp.Ca6. Int. J. Biol. Macromol. 2017, 103, 194-201. [CrossRef] [PubMed]

220. Jeong, D.; Kim, D.-H.; Kang, I.-B.; Kim, H.; Song, K.-Y.; Kim, H.-S.; Seo, K.-H. Characterization and antibacterial activity of a novel exopolysaccharide produced by Lactobacillus kefiranofaciens DN1 isolated from kefir. Food Control 2017, 78, 436-442. [CrossRef]

221. Adebayo-Tayo, B.C.; Popoola, A.O. Biogenic synthesis and antimicrobial activity of silver nanoparticle using exopolysaccharides from lactic acid bacteria. Int. J. Nano Dimens. 2017, 8, 61-69. [CrossRef]

222. Álvarez, A.; Manjarres, J.J.; Ramírez, C.; Bolívar, G. Use of an exopolysaccharide-based edible coating and lactic acid bacteria with antifungal activity to preserve the postharvest quality of cherry tomato. LWT 2021, 151, 112225. [CrossRef]

223. Nagai, T.; Makino, S.; Ikegami, S.; Itoh, H.; Yamada, H. Effects of oral administration of yogurt fermented with Lactobacillus delbrueckii ssp. bulgaricus OLL1073R-1 and its exopolysaccharides against influenza virus infection in mice. Int. Immunopharmacol. 2011, 11, 2246-2250. [CrossRef] [PubMed]

224. Abd El Ghany, K.; Hamouda, R.; Abd Elhafez, E.; Mahrous, H.; Salem-Bekhit, M.; Hamza, H.A. A potential role of Lactobacillus acidophilus LA1 and its exopolysaccharides on cancer cells in male albino mice. Biotechnol. Biotechnol. Equip. 2015, 29, 977-983. [CrossRef]

225. Deepak, V.; Ram Kumar Pandian, S.; Sivasubramaniam, S.D.; Nellaiah, H.; Sundar, K. Optimization of anticancer exopolysaccharide production from probiotic Lactobacillus acidophilus by response surface methodology. Prep. Biochem. Biotechnol. 2016, 46, 288-297. [CrossRef]

226. Gao, F.; Li, L.; Zhang, H.; Yang, W.; Chen, H.; Zhou, J.; Zhou, Z.; Wang, Y.; Cai, Y.; Li, X. Deoxycholic acid modified-carboxymethyl curdlan conjugate as a novel carrier of epirubicin: In vitro and in vivo studies. Int. J. Pharm. 2010, 392, 254-260. [CrossRef]

227. Liang, T.-W.; Wu, C.-C.; Cheng, W.-T.; Chen, Y.-C.; Wang, C.-L.; Wang, I.-L.; Wang, S.-L. Exopolysaccharides and antimicrobial biosurfactants produced by Paenibacillus macerans TKU029. Appl. Biochem. Biotechnol. 2014, 172, 933-950. [CrossRef]

228. Mohd Nadzir, M.; Nurhayati, R.W.; Idris, F.N.; Nguyen, M.H. Biomedical applications of bacterial exopolysaccharides: A review. Polymers 2021, 13, 530. [CrossRef] [PubMed]

229. Wang, B.; Han, Y.; Lin, Q.; Liu, H.; Shen, C.; Nan, K.; Chen, H. In vitro and in vivo evaluation of xanthan gum-succinic anhydride hydrogels for the ionic strength-sensitive release of antibacterial agents. J. Mater. Chem. B 2016, 4, 1853-1861. [CrossRef] [PubMed]

230. Li, W.; Ji, J.; Rui, X.; Yu, J.; Tang, W.; Chen, X.; Jiang, M.; Dong, M. Production of exopolysaccharides by Lactobacillus helveticus MB2-1 and its functional characteristics in vitro. LWT Food Sci. Technol. 2014, 59, 732-739. [CrossRef] 